U.S. Department of the Interior

U.S. Geological Survey

Prepared in cooperation with

Idaho Power Company

\title{
Organochlorine Compounds and Trace Elements in Fish Tissue and Bed Sediments in the Lower Snake River Basin, Idaho and Oregon
}

Water-Resources Investigations Report 98-4103

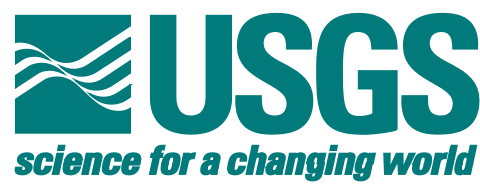




\section{Organochlorine Compounds and Trace Elements in Fish Tissue and Bed Sediments in the Lower Snake River Basin, Idaho and Oregon}

By Gregory M. Clark and Terry R. Maret

Water-Resources Investigations Report 98-4103

Prepared in cooperation with Idaho Power Company

Boise, Idaho 


\section{U.S. DEPARTMENT OF THE INTERIOR}

BRUCE BABBITT, Secretary

\section{U.S. GEOLOGICAL SURVEY}

Thomas J. Casadevall, Acting Director

Any use of trade, product, or firm names in this report is for descriptive purposes only and does not imply endorsement by the U.S. Government.

For additional information write to: District Chief 230 Collins Road Boise, ID 83702-4520
Copies of this report can be purchased from: U.S. Geological Survey Information Services Box 25286

Denver Federal Center Denver, CO 80225 


\section{CONTENTS}

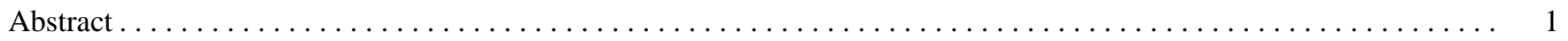

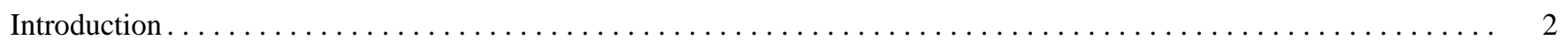

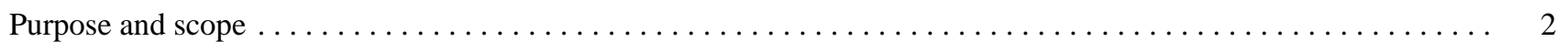

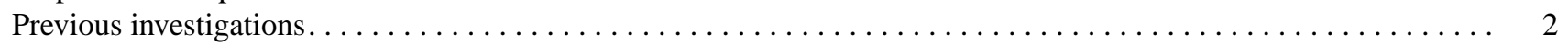

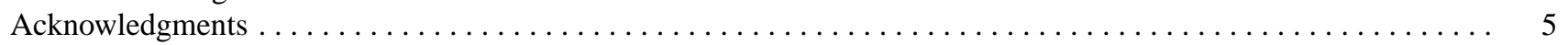

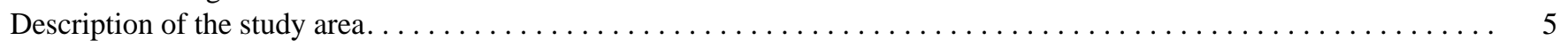

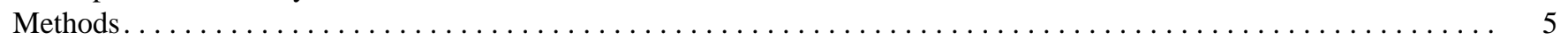

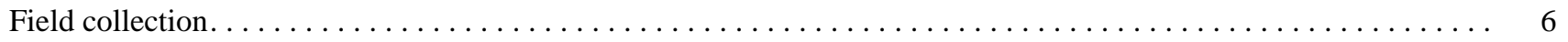

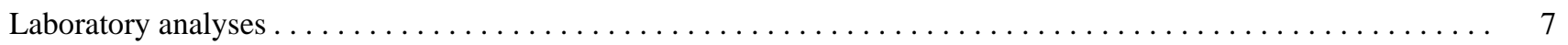

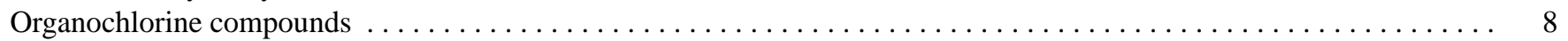

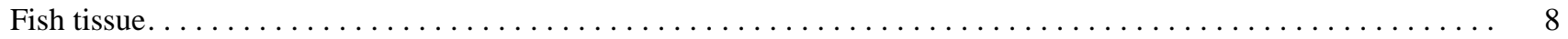

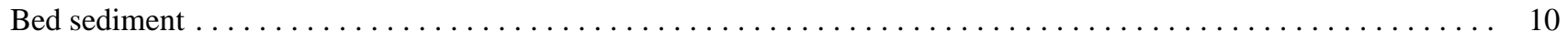

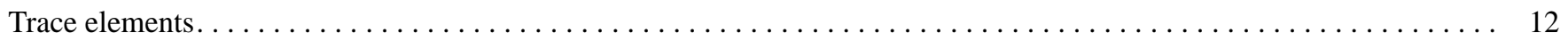

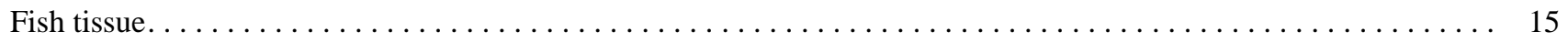

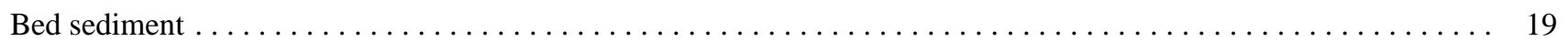

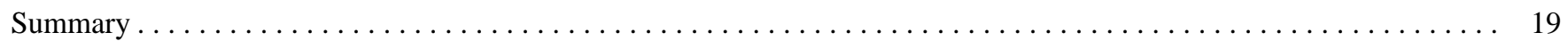

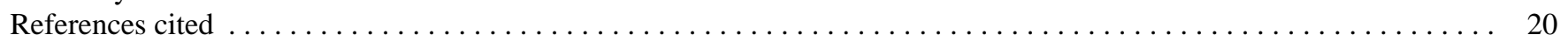

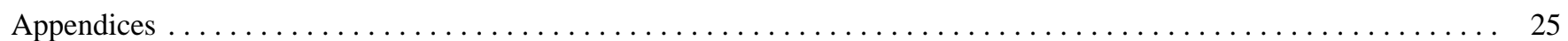

\section{FIGURES}

1. Map showing sites in the lower Snake River Basin where fish-tissue and(or) bed-sediment samples were collected for analysis of organochlorine compounds and(or) trace elements, August and September 1997 . . . . . .

2. Graph showing concentrations of selected organochlorine compounds in fish-tissue samples from the lower Snake River Basin, August and September $1997 \ldots \ldots \ldots \ldots \ldots \ldots \ldots \ldots \ldots$

3. Map showing additional sites in the Snake River Basin where fish-tissue and(or) bed-sediment samples were collected for analysis of organochlorine compounds and(or) trace elements, $1992-97 \ldots \ldots \ldots \ldots \ldots$

4-9. Graphs showing:

4. Concentrations of total DDT and total organochlorine compounds in suckers from the Snake River, Snake River reservoirs, and Snake River tributaries, $1992-97 \ldots \ldots \ldots \ldots \ldots \ldots \ldots$

5. Concentrations of total organochlorine compounds in bed sediment from the Snake River, Snake River

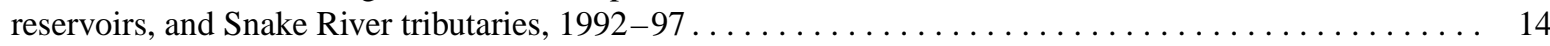

6. Concentrations of selected trace elements in fish-tissue samples from the lower Snake River Basin,

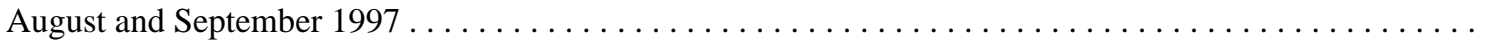

7. Sum concentrations of selected trace elements in liver samples of suckers from the Snake River Basin,

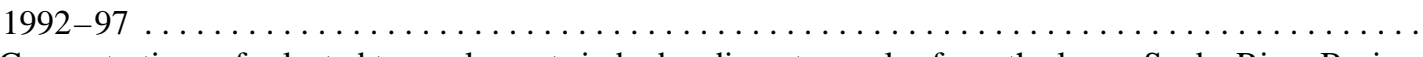

8. Concentrations of selected trace elements in bed-sediment samples from the lower Snake River Basin,

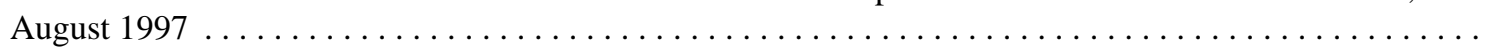

9. Sum concentrations of selected trace elements in bed-sediment samples from the Snake River Basin,

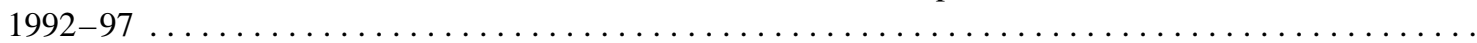

\section{TABLES}

1. Sites in the lower Snake River Basin where fish-tissue and(or) bed-sediment samples were collected,

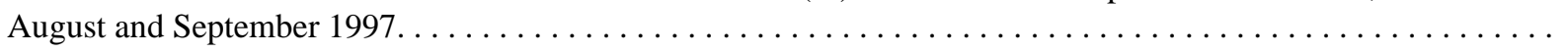

2. Taxa and physical characteristics of fish collected from the lower Snake River Basin for analysis of organochlorine compounds and trace elements, August and September 1997. . . . . . . . . . . . . . . .

3. Organochlorine compounds and trace elements for which fish-tissue samples from the lower Snake River

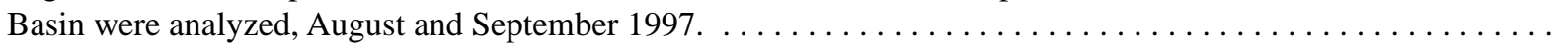


4. Organochlorine compounds, carbon content, and trace elements for which bed-sediment samples from the lower Snake River Basin were analyzed, August and September $1997 \ldots \ldots \ldots \ldots$

5. Additional sites in the Snake River Basin where fish-tissue and bed-sediment samples were collected and analyzed for organochlorine compounds and trace elements, $1992-97 \ldots \ldots \ldots \ldots \ldots$

\title{
CONVERSION FACTORS, VERTICAL DATUM, AND ABBREVIATED WATER-QUALITY UNITS
}

\begin{tabular}{rcl}
\hline Multiply & By & To obtain \\
\hline acre-foot $($ acre-ft) & 1,233 & cubic meter \\
cubic foot $\left(\mathrm{ft}^{3}\right)$ & 0.02832 & cubic meter \\
cubic foot per second $\left(\mathrm{ft}^{3} / \mathrm{s}\right)$ & 0.02832 & cubic meter per second \\
foot $(\mathrm{ft})$ & 0.3048 & meter \\
inch (in.) & 2.54 & centimeter \\
mile (mi) & 1.609 & kilometer \\
square mile $\left(\mathrm{mi}^{2}\right)$ & 2.590 & square kilometer
\end{tabular}

Temperature in degrees Fahrenheit $\left({ }^{\circ} \mathrm{F}\right)$ can be converted to degrees Celsius $\left({ }^{\circ} \mathrm{C}\right)$ as follows:

$$
{ }^{\circ} \mathrm{C}=5 / 9\left({ }^{\mathrm{O}} \mathrm{F}-32\right)
$$

Sea level: In this report, "sea level" refers to the National Geodetic Vertical Datum of 1929-a geodetic datum derived from a general adjustment of the first-order level nets of the United States and Canada, formerly called Sea Level Datum of 1929.

\author{
Abbreviated water-quality units used in report: \\ $\mu \mathrm{g} / \mathrm{kg} \quad$ microgram per kilogram (parts per billion) \\ $\mu \mathrm{g} / \mathrm{g} \quad$ microgram per gram (parts per million) \\ $\mu \mathrm{m} \quad$ micrometer
}





\title{
Organochlorine Compounds and Trace Elements in Fish Tissue and Bed Sediments in the Lower Snake River Basin, Idaho and Oregon
}

\author{
By Gregory M. Clark and Terry R. Maret
}

\section{ABSTRACT}

Fish-tissue and bed-sediment samples were collected to determine the occurrence and distribution of organochlorine compounds and trace elements in the lower Snake River Basin. Whole-body composite samples of suckers and carp from seven sites were analyzed for organochlorine compounds; liver samples were analyzed for trace elements. Fillets from selected sportfish were analyzed for organochlorine compounds and trace elements. Bed-sediment samples from three sites were analyzed for organochlorine compounds and trace elements.

Twelve different organochlorine compounds were detected in 14 fish-tissue samples. All fish-tissue samples contained DDT or its metabolites. Concentrations of total DDT ranged from 11 micrograms per kilogram wet weight in fillets of yellow perch from C.J. Strike Reservoir to 3,633 micrograms per kilogram wet weight in a whole-body sample of carp from Brownlee Reservoir at Burnt River. Total DDT concentrations in whole-body samples of sucker and carp from the Snake River at C.J. Strike Reservoir, Snake River at Swan Falls, Snake River at Nyssa, and Brownlee Reservoir at Burnt River exceeded criteria established for the protection of fish-eating wildlife. Total PCB concentrations in a whole-body sample of carp from Brownlee Reservoir at Burnt River also exceeded fish-eating wildlife criteria.

Concentrations of organochlorine compounds in whole-body samples, in general, were larger than concentrations in sportfish fillets. However, concentrations of dieldrin and total DDT in fillets of channel catfish from the Snake River at Nyssa and Brownlee Reservoir at Burnt River, and concentrations of total DDT in fillets of smallmouth bass and white crappie from Brownlee Reservoir at Burnt River exceeded a cancer risk screening value of $10^{-6}$ established by the U.S. Environmental Protection Agency. Concentrations of organochlorine compounds in bed sediment were smaller than concentrations in fish tissue. Concentrations of p,p'DDE, the only compound detected in all three bed-sediment samples, ranged from 1.1 micrograms per kilogram dry weight in C.J. Strike Reservoir to 11 micrograms per kilogram dry weight in Brownlee Reservoir at Burnt River. Data from this study, compared with data collected in the upper Snake River Basin from 1992 to 1994, indicates that, in general, organochlorine concentrations in fish tissue and bed sediment increased from the headwaters of the Snake River in Wyoming downstream to Brownlee Reservoir.

The largest trace-element concentrations in fish tissue were in liver samples from carp from Brownlee Reservoir at Burnt River and suckers from the Boise River near Twin Springs. Concentrations of most trace elements were larger in livers than in the sportfish fillets. However, mercury concentrations were generally larger in the sportfish fillets; they ranged from 0.08 microgram per gram wet weight in yellow perch from C.J. Strike Reservoir to 0.32 microgram per gram wet weight in channel catfish from Brownlee Reservoir at Burnt River. None of the trace-element concentrations in fillets exceeded median international standards or U.S. Food and Drug Administration action levels. Large trace-element concentrations in the upper Snake River Basin were reported in liver samples from suckers from headwater streams, probably a result of historical mining and weathering of metal-rich rocks.

Concentrations of most trace elements in the bed-sediment samples were largest in Brownlee Reservoir at Mountain Man Lodge. Concentrations of 
arsenic, cadmium, chromium, copper, nickel, and zinc in bed sediment from the Mountain Man Lodge site exceeded either the threshold effect level or probable effect level established by the Canadian Government for the protection of benthic life. Arsenic, chromium, copper, and nickel concentrations in bed sediment from Brownlee Reservoir at Burnt River and chromium, copper, and nickel in bed sediment from C.J. Strike Reservoir also exceeded the threshold effect level.

\section{INTRODUCTION}

Concern about contaminants in streams in the Snake River Basin has increased in recent years. Studies have detected elevated concentrations of some organochlorine compounds and trace elements in fish tissue and bed sediment in parts of the Snake River Basin (Rinella and others, 1994; Maret, 1995b; Maret and Ott, 1997; Oregon Department of Human Resources, written commun., 1997). Although the concentrations of contaminants were not alarmingly high, some exceeded human health criteria and guidelines established for the protection of aquatic life. The presence of organochlorine compounds and trace elements in aquatic systems may be attributed to natural sources and(or) past and present land use. Although trace elements are primarily from natural sources, human activities such as mining, agriculture, and urbanization may strongly affect their concentration and distribution. Conversely, synthetic organochlorine compounds are manufactured solely for human use and can, therefore, be related directly to human activities (Larson and others, 1997).

\section{Purpose and Scope}

This report presents the results of a reconnaissance level assessment of organochlorine compounds and trace elements in fish tissue and bed sediment at selected sites in the lower Snake River Basin in southwestern Idaho and eastern Oregon. The results of this study are compared with criteria established for protection of human health and guidelines established for the protection of aquatic life and fish-eating wildlife. The results also are compared with results from previous investigations of contaminants in the upper Snake River Basin in western Wyoming and southeastern Idaho. Results from this study can be used to identify specific constituents of concern and will provide a baseline for future studies to determine sources, transport, and biological effects of contaminants in the Snake River Basin. This study was conducted in cooperation with the Idaho Power Company.

\section{Previous Investigations}

Several studies and data-collection activities have been conducted along the Snake River and its tributaries to assess organochlorine and trace-element contamination in fish tissue and bed sediment. Contaminants that have been detected in concentrations that exceed health criteria and(or) aquatic life guidelines include DDT and its metabolites, polychlorinated biphenyls (PCBs), toxaphene, and mercury (Maret, 1995b). Consumption of some fish species from the Snake River in southwestern Idaho and along the Idaho-Oregon border and in some lower Snake River tributaries has been recognized as a potential human health concern because of mercury contamination (U.S. Environmental Protection Agency, 1996).

The U.S. Geological Survey (USGS), as part of its National Water-Quality Assessment (NAWQA) Program, examined contaminants in fish tissue and bed sediment in the Snake River Basin upstream from King Hill (upper Snake River Basin) (fig. 1). Fourteen different organochlorine compounds were detected in fishtissue samples and 9 in bed-sediment samples collected at 20 sites during 1992-94 (Maret and Ott, 1997). The most commonly detected compounds were p,p'DDE (a breakdown product or metabolite of DDT), present in 80 percent of fish-tissue and 30 percent of bed-sediment samples, and PCBs, present in 55 percent of fishtissue and 5 percent of bed-sediment samples. Streams with sites where concentrations of organochlorine compounds in fish tissue exceeded National Academy of Sciences/National Academy of Engineering (NAS/NAE) guidelines for the protection of fish-eating wildlife (NAS/NAE, 1973) included the Portneuf River, Rock Creek, and the Snake River near Twin Falls. However, fish-tissue data collected from the Snake River near Twin Falls by the U.S. Fish and Wildlife Service during 1970-84 (Lowe and others, 1985) and data collected during the upper Snake River Basin NAWQA study (Maret and Ott, 1997) indicate that concentrations of DDT in fish-tissue samples declined significantly from the time that DDT was banned from manufacture, 1974 , to the time when the NAWQA samples were col- 


\section{EXPLANATION}

Sample site-Site identifications Snk-BR listed in table 1
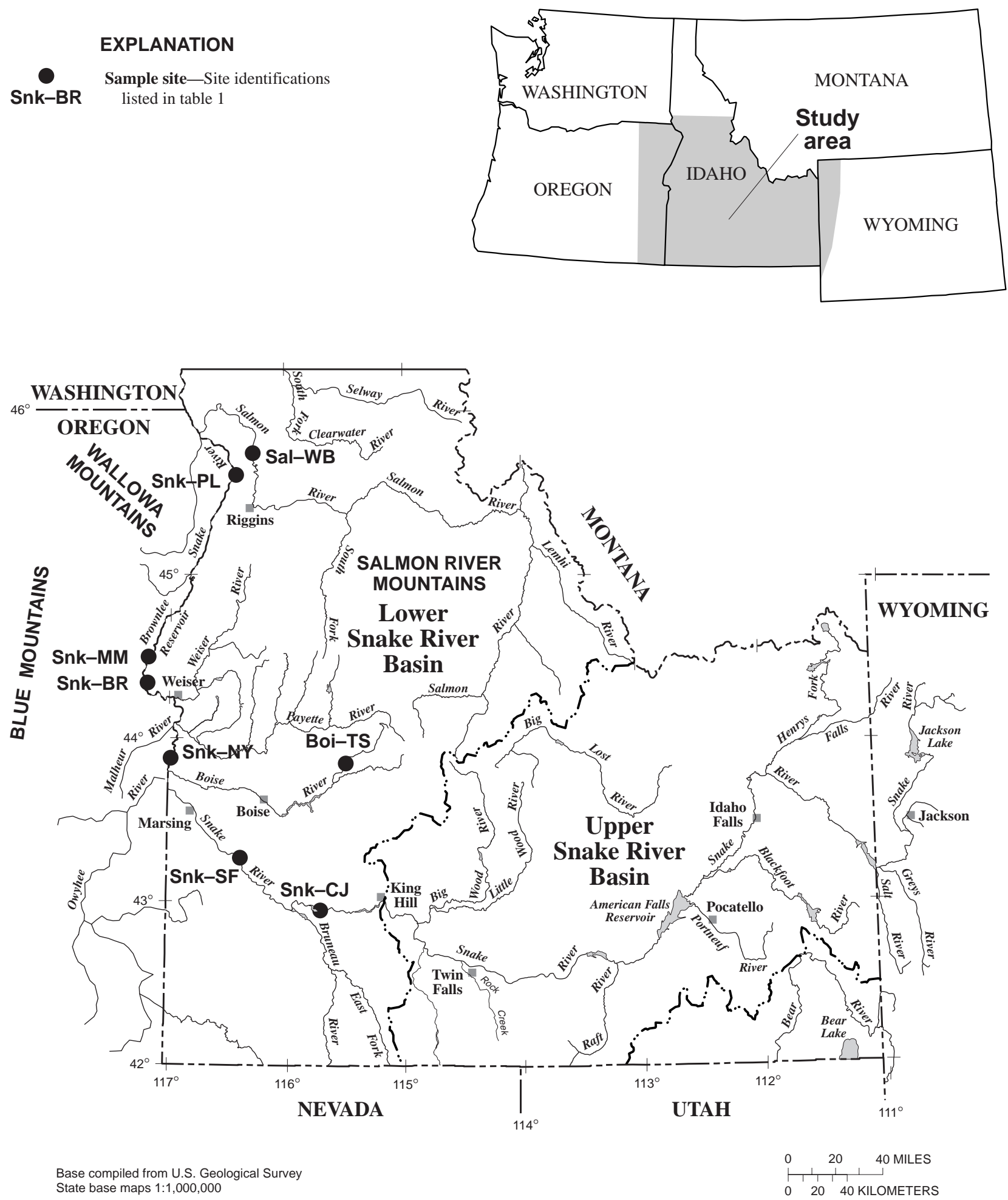

Figure 1. Sites in the lower Snake River Basin where fish-tissue and(or) bed-sediment samples were collected for analysis of organochlorine compounds and(or) trace elements, August and September 1997. 
lected, 1992-94. Concentrations of p,p'DDE in three bed-sediment samples collected during 1992-94 from Rock Creek near Twin Falls exceeded Sediment Quality Probable Effect Level (PEL) guidelines established by the Canadian Government for the prevention of biological impairment (Canadian Council of Ministers of the Environment, 1995).

NAWQA data indicate that concentrations of some trace elements in fish tissue and bed sediment are elevated in some headwater parts of the upper Snake River Basin, primarily the northern mountainous region (Clark and others, 1998). This enrichment can be attributed to historical mining and the composition of rocks in the region. Mercury in tissue and bed sediment of the upper Snake River Basin, however, was not found at concentrations considered a threat to the health of humans and(or) wildlife (Maret, 1995a). Concentrations of mercury in tissue from caddisfly larvae and livers from fish in the upper Snake River Basin were all less than $0.1 \mu \mathrm{g} / \mathrm{g}^{1}$, the maximum recommended by Eisler (1987) for protection of fish-eating birds and wildlife. The NAWQA data also indicate that, unlike most trace elements, mercury concentrations in bed sediment and tissue, in general, increase downstream in the main stem of the Snake River (Maret, 1995a). The largest concentration of mercury in tissue was $0.044 \mu \mathrm{g} / \mathrm{g}$ in a liver sample from largescale suckers from the Snake River at King Hill.

In 1990, the U.S. Department of the Interior (DOI) began an irrigation drainage study in the Owyhee and Malheur River Basins of Oregon (fig. 1) and along the Snake River from about Marsing, Idaho, downstream to Brownlee Reservoir on the Idaho-Oregon border (Rinella and others, 1994). The purpose of that study was to determine whether contaminants in irrigation drainage have been or could be harmful to human health, fish, and wildlife, or could impair other beneficial uses of water.

The DOI study documented that organochlorine compounds were present in most of the fish-tissue samples collected from the Snake River since the mid1980's. Samples of fish tissue from Brownlee Reservoir, the Owyhee River, and the Malheur River con-

\footnotetext{
${ }^{1}$ Organochlorine and trace-element concentrations in all tissue samples discussed in this report (excluding appendix 3) are based on wet weight. Concentrations in bed-sediment samples are based on dry weight. To convert dry-weight concentrations to wet-weight concentrations, multiply the dry-weight concentration by a factor of 1 minus the percentage of moisture content expressed as a decimal.
}

tained concentrations of total DDT that exceeded the NAS/NAE guideline for the protection of fish-eating wildlife (Rinella and others, 1994). Concentrations of total DDT were detected in 14 of 16 fish-tissue samples and ranged from less than the analytical reporting level to $2,250 \mu \mathrm{g} / \mathrm{kg}$. Other organochlorine compounds detected in fish-tissue samples included chlordane, dieldrin, heptachlor epoxide, nonachlor, and toxaphene. Concentrations of toxaphene and p,p'DDE in some fish-tissue samples also exceeded the NAS/NAE guideline.

The DOI study found 8 organochlorine compounds in bed-sediment samples from 14 sites. Concentrations of p,p'DDE were detected at all 14 sites, dieldrin at 13 sites, and chlordane at 11 sites. Concentrations of p,p'DDE, dieldrin, and chlordane exceeded the PEL established for the protection of benthic life (Canadian Council of Ministers of the Environment, 1995) at 9, 2, and 1 sites, respectively.

Elevated mercury concentrations in tissue of fish from Brownlee Reservoir and the Owyhee River have raised concerns about human health and fish consumption. The Oregon Department of Fish and Wildlife found mercury concentrations as high as $1.77 \mu \mathrm{g} / \mathrm{g}$ in fillets of smallmouth bass from the Owyhee River Basin (Ken Kauffman, Oregon Department of Environmental Quality, written commun., 1997); the Food and Drug Administration (FDA) guideline for mercury residues in human foods is $1.0 \mu \mathrm{g} / \mathrm{g}$. Other fish species in the lower Snake River Basin that contained mercury concentrations in excess of $1.0 \mu \mathrm{g} / \mathrm{g}$ include channel catfish, largemouth bass, white crappie, and northern squawfish (Brian Abbott, Idaho Department of Health and Welfare, written commun., 1997).

Concentrations of mercury in fillets of channel catfish collected from Brownlee Reservoir during 196970 all exceeded the median international standard of $0.5 \mu \mathrm{g} / \mathrm{g}$ (Buhler and others, 1973). Followup studies in 1970 determined that mercury concentrations in the muscle tissue of seven species of fish from Brownlee Reservoir ranged from $0.24 \mu \mathrm{g} / \mathrm{g}$ in common carp to $0.73 \mu \mathrm{g} / \mathrm{g}$ in northern squawfish (Gebhards and others, 1973). Mercury was detected in all the fish-tissue samples collected in 1990 as part of the DOI irrigation drainage study (Rinella and others, 1994); the largest concentrations were in tissue of fish from the Owyhee River Basin $(0.07-0.76 \mu \mathrm{g} / \mathrm{g})$. Mercury concentrations in whole-body samples of fish from the Snake River ranged from 0.13 to $0.42 \mu \mathrm{g} / \mathrm{g}$ in common carp; 0.10 to $0.33 \mu \mathrm{g} / \mathrm{g}$ in channel catfish; and 0.13 to $0.23 \mu \mathrm{g} / \mathrm{g}$ in 
bass and crappie (Rinella and others, 1994). Mercury concentrations in fillets of sportfish collected from Brownlee Reservoir in 1994 and 1995 by the Idaho Department of Fish and Game ranged from 0.10 to $0.80 \mu \mathrm{g} / \mathrm{g}$; concentrations in about 30 percent of the samples exceeded the median international standard of $0.5 \mu \mathrm{g} / \mathrm{g}$ (Brian Abbott, Idaho Department of Health and Welfare, written commun., 1997). The elevated concentrations of mercury in fish have resulted in the issuance of consumption guidelines for people eating fish caught from Brownlee Reservoir and the Owyhee River (Ken Kauffman, Oregon Department of Environmental Quality, written commun., 1997). The source of the mercury is thought to be volcanic rocks and geothermal deposits in the drainage area, possibly exacerbated by historical mining.

\section{Acknowledgments}

The authors would like to thank Idaho Power Company for funding this study and for providing logistical and personnel support during sample collection. The authors also acknowledge the Idaho Department of Fish and Game, and Douglas S. Ott and Kenneth D. Skinner from the U.S. Geological Survey, for their assistance in sample collection.

\section{DESCRIPTION OF THE STUDY AREA}

The Snake River, the largest tributary in the Columbia River drainage basin, drains about 109,000 $\mathrm{mi}^{2}$ of variable topography, including nearly all of Idaho and parts of five bordering States. About $40,000 \mathrm{mi}^{2}$, or 37 percent, of the total basin area is drained by the Snake River between King Hill, Idaho (the outlet of the upper Snake River Basin), and its confluence with the Salmon River on the Idaho-Oregon border (fig. 1). This intervening drainage area (in this report referred to as the lower Snake River Basin) is bounded on the south by the high plateau areas of northern Nevada and eastern Oregon, on the north and east by the mountains of central Idaho, and on the west by the Blue and Wallowa Mountains of Oregon (Laird, 1964). Climate of the lower Snake River Basin ranges from arid in the lowlands to subhumid in the mountains; annual precipitation ranges from about 8 in. in the arid lowlands of southwestern Idaho and southeastern Oregon to $60 \mathrm{in}$. in the central Idaho mountains (Laird, 1964). Most of the land in the basin is federally owned and managed by the Bureau of Land Management or the National Forest Service. Irrigated agriculture is practiced along the margins of the Snake River for much of its length from King Hill downstream to Weiser and in lowland areas of rivers tributary to the Snake River. Primary crops grown include alfalfa, barley, beans, corn, mint, potatoes, sugar beets, and wheat. Nearly all crops are irrigated, primarily with water diverted or pumped from streams and reservoirs.

The elevation of the Snake River drops almost 1,600 ft in the $357 \mathrm{mi}$ from King Hill (elevation 2,498 $\mathrm{ft}$ above sea level) to the confluence of the Snake and Salmon Rivers (elevation $905 \mathrm{ft}$ ). About 75 percent of the elevation loss is in the $100 \mathrm{mi}$ from Brownlee Dam to the confluence of the Snake and Salmon Rivers. Primary tributaries to the Snake River downstream from King Hill to Brownlee Reservoir are the Bruneau, Owyhee, Boise, Malheur, Payette, and Weiser Rivers. In water year 1996, these tributaries discharged nearly $11,000 \mathrm{ft}^{3} / \mathrm{s}$ of water to the Snake River and accounted for about 40 percent of the Snake River discharge entering Brownlee Reservoir. Reservoirs along the lower Snake River are C.J. Strike, Swan Falls, Brownlee, Oxbow, and Hells Canyon. Combined reservoir storage capacity is about 2 million acre-ft; Brownlee Reservoir accounts for about 75 percent (Brennan and others, 1997).

\section{METHODS}

Most organochlorine compounds and trace elements are not highly water soluble; rather, they sorb to sediments and accumulate along stream bottoms. Once contaminants reach the stream bottom, they can be ingested by benthic organisms and subsequently work their way through the aquatic food chain where they can bioaccumulate in animal tissue (Blus, 1996). Thus, analyzing for organochlorine compounds and trace elements in fish tissue and bed sediment increases the probability of detections in the environment. Measurements of concentrations in fish tissue and bed sediments also provide a time-integrated assessment for these contaminants and provide an indicator of potential risk to human health and wildlife. These media, therefore, are excellent tools for assessing current, as well as historical, organochlorine and trace-element contamination in aquatic ecosystems. 


\section{Field Collection}

For this study, fish-tissue and bed-sediment samples were collected at seven and three sites, respectively, along the Snake River and selected tributaries from C.J. Strike Reservoir to the confluence of the Snake and Salmon Rivers (fig. 1). All samples were collected during base-flow conditions in August and September 1997. Table 1 lists locations of the sampling sites and the associated samples collected at each site.

Fish were collected by electrofishing following the procedures outlined by Meador and others (1993). Largescale suckers (Catostomus macrocheilus) from all sites and common carp (Cyprinus carpio) from Brownlee Reservoir were analyzed for organochlorine compounds in whole-body samples and for trace elements in liver samples. In addition to whole-body and liver analyses on suckers and carp, selected sportfish from
Table 1. Sites in the lower Snake River Basin where fishtissue and(or) bed-sediment samples were collected, August and September 1997

[Site locations are shown in figure 1; ID, Idaho; OR, Oregon; X, sample(s) collected; - , sample not collected; whl, whole-body samples collected for organochlorine analysis and livers collected for trace-element analysis; flt, fillet samples from selected sportfish collected for organochlorine and traceelement analysis; QA, quality-assurance sample]

\begin{tabular}{|c|c|c|c|}
\hline $\begin{array}{c}\text { Site } \\
\text { identification }\end{array}$ & Site name & $\begin{array}{l}\text { Body part } \\
\text { analyzed }\end{array}$ & $\begin{array}{c}\text { Bed } \\
\text { sediment }\end{array}$ \\
\hline Snk-CJ & $\begin{array}{l}\text { C.J. Strike Reservoir at } \\
\text { Highway } 51 \text { Bridge, ID }\end{array}$ & $\begin{array}{c}\mathrm{X} \\
\text { (1 whl, } 2 \mathrm{flt})\end{array}$ & $\mathrm{X}$ \\
\hline Snk-SF & $\begin{array}{l}\text { Swan Falls Reservoir at } \\
\text { Swan Falls Dam, ID }\end{array}$ & $\begin{array}{c}\mathrm{X} \\
(1 \mathrm{whl})\end{array}$ & - \\
\hline Boi-TS & $\begin{array}{l}\text { Boise River near Twin } \\
\text { Springs, ID }\end{array}$ & $\begin{array}{c}\mathrm{X} \\
(1 \mathrm{whl})\end{array}$ & - \\
\hline Snk-NY & Snake River at Nyssa, OR & $\begin{array}{c}\mathrm{X} \\
(1 \mathrm{whl}, 1 \mathrm{flt})\end{array}$ & - \\
\hline Snk-BR & $\begin{array}{l}\text { Brownlee Reservoir at } \\
\text { Burnt River, OR }\end{array}$ & $\underset{(2 \mathrm{whl}, 3 \mathrm{flt})}{\mathrm{X}}$ & $\mathrm{X}$ \\
\hline Snk-MM & $\begin{array}{l}\text { Brownlee Reservoir at } \\
\quad \text { Mountain Man Lodge, OR }\end{array}$ & - & $\mathrm{X}$ \\
\hline Snk-PL & $\begin{array}{l}\text { Snake River at Pittsburg } \\
\text { Landing, ID }\end{array}$ & $\begin{array}{c}\mathrm{X} \\
\text { (1 whl, } 1 \text { whl QA) }\end{array}$ & - \\
\hline Sal-WB & $\begin{array}{l}\text { Salmon River near } \\
\text { White Bird, ID }\end{array}$ & $\begin{array}{c}\mathrm{X} \\
(1 \mathrm{whl})\end{array}$ & - \\
\hline
\end{tabular}

Table 2. Taxa and physical characteristics of fish collected from the lower Snake River Basin for analysis of organochlorine compounds and trace elements, August and September 1997

[Sample site locations are shown in figure 1 and listed in table 1; mm, millimeter; g, gram; whl, whole body; liv, liver; flt, fillet; org, organochlorine compounds; te, trace elements; QA, quality-assurance sample]

\begin{tabular}{|c|c|c|c|c|c|c|c|c|}
\hline $\begin{array}{c}\text { Site } \\
\text { identification }\end{array}$ & $\begin{array}{l}\text { Taxa collected } \\
\text { (common name) }\end{array}$ & $\begin{array}{l}\text { Body part } \\
\text { analyzed }\end{array}$ & $\begin{array}{l}\text { Type of } \\
\text { analysis }\end{array}$ & $\begin{array}{l}\text { No. of } \\
\text { fish }\end{array}$ & $\begin{array}{l}\text { Total length } \\
(\mathrm{mm})\end{array}$ & $\begin{array}{c}\text { Mean length } \\
(\mathrm{mm})\end{array}$ & $\begin{array}{l}\text { Weight } \\
\text { (g) }\end{array}$ & $\begin{array}{c}\text { Mean weight } \\
(\mathrm{g})\end{array}$ \\
\hline \multirow[t]{4}{*}{ Snk-CJ } & Largescale sucker & whl & org & 6 & $465-526$ & 491 & $944-1,330$ & 1,128 \\
\hline & Largescale sucker & liv & te & 6 & $435-620$ & 513 & $935-2,742$ & 1,407 \\
\hline & Smallmouth bass & flt & org, te & 5 & $304-364$ & 333 & $378-698$ & 515 \\
\hline & Yellow perch & flt & org, te & 7 & $180-224$ & 201 & $73-135$ & 94 \\
\hline \multirow[t]{2}{*}{ Snk-SF } & Largescale sucker & whl & org & 6 & $475-554$ & 516 & $1,060-1,523$ & 1,279 \\
\hline & Largescale sucker & liv & te & 6 & $500-600$ & 538 & $920-1,836$ & 1,397 \\
\hline \multirow[t]{2}{*}{ Boi-TS } & Largescale sucker & whl & org & 8 & $380-444$ & 413 & $465-786$ & 645 \\
\hline & Largescale sucker & liv & te & 7 & $353-505$ & 427 & $421-1,186$ & 743 \\
\hline \multirow[t]{3}{*}{ Snk-NY } & Largescale sucker & whl & org & 7 & $478-565$ & 510 & $953-1,657$ & 1,302 \\
\hline & Largescale sucker & liv & te & 7 & $471-530$ & 507 & $977-1,499$ & 1,272 \\
\hline & Channel catfish & flt & org, te & 8 & $456-555$ & 514 & $800-1,736$ & 1,283 \\
\hline \multirow[t]{7}{*}{ Snk-BR } & Largescale sucker & whl & org & 7 & $475-570$ & 525 & $1,010-2,236$ & 1,611 \\
\hline & Largescale sucker & liv & te & 7 & $405-575$ & 516 & $690-2,340$ & 1,619 \\
\hline & Common carp & whl & org & 5 & $540-685$ & 648 & $2,477-4,939$ & 3,932 \\
\hline & Common carp & liv & te & 5 & $570-770$ & 675 & $2,898-6,550$ & 4,602 \\
\hline & Smallmouth bass & flt & org, te & 6 & $230-260$ & 244 & $142-236$ & 182 \\
\hline & White crappie & flt & org, te & 5 & $220-308$ & 246 & $157-382$ & 224 \\
\hline & Channel catfish & flt & org, te & 7 & $380-480$ & 439 & $551-1,020$ & 833 \\
\hline \multirow[t]{4}{*}{ Snk-PL } & Largescale sucker & whl & org & 7 & $410-525$ & 454 & $577-1,167$ & 812 \\
\hline & Largescale sucker & $\operatorname{liv}$ & te & 7 & $405-520$ & 458 & $635-1,149$ & 834 \\
\hline & Largescale sucker (QA) & whl & org & 7 & $430-535$ & 469 & $644-1,294$ & 829 \\
\hline & Largescale sucker (QA) & $\operatorname{liv}$ & te & 7 & $400-485$ & 450 & $618-919$ & 788 \\
\hline \multirow[t]{2}{*}{ Sal-WB } & Largescale sucker & whl & org & 7 & $435-505$ & 475 & $781-1,135$ & 944 \\
\hline & Largescale sucker & liv & te & 7 & $405-500$ & 458 & $676-1,066$ & 947 \\
\hline
\end{tabular}


three sites were analyzed for contaminants in the edible portion, or fillet, using techniques described by the U.S. Environmental Protection Agency (1995). Fifteen tissue samples - 8 whole body, 1 whole body for quality assurance (QA), and 6 fillet-were analyzed for organochlorine compounds, and 15 tissue samples -8 liver, 1 liver QA, and 6 fillet - were analyzed for trace elements.

At each site, five to eight adult fish of the same species and of similar size were composited for analysis. Fish were held in clean plastic buckets to avoid contamination during processing in a mobile laboratory. The collected fish were identified to species and measured for length and weight (table 2). Whole-body samples for organochlorine analyses were wrapped in aluminum foil and placed in plastic bags. Liver samples extracted from suckers and carp for trace-element analyses were composited in plastic containers. Fillets from sportfish were collected by removing a fillet from both sides of each fish and then removing the skin. One fillet from each fish was composited for analyses of organochlorine compounds and the other fillet was composited for analyses of trace elements. All samples were frozen onsite with dry ice and shipped to the USGS National Water Quality Laboratory (NWQL) in Arvada, Colorado, for analysis. Further details on tissue-sampling methods used in this study are included in a report by Crawford and Luoma (1993).

Bed-sediment samples were collected using the procedures described by Shelton and Capel (1994). A representative sample was obtained by collecting and compositing fine-grained surficial sediments from numerous depositional zones at a site. Samples were collected using a stainless-steel ponar dredge, composited in a glass bowl, and homogenized for subsequent processing. Bed-sediment samples analyzed for organochlorine compounds were wet sieved, using native water, through a $2-\mathrm{mm}$ stainless-steel sieve into a precleaned 1-L (0.3-gallon) glass jar. An additional sample was sieved into a 500-mL (17-ounce) plastic container for particle-size analysis. Bed-sediment samples analyzed for trace elements were wet sieved, using native water, through a $63-\mu \mathrm{m}$ mesh nylon-sieve cloth held in a plastic frame. Samples for trace-element analyses were collected in 500-mL plastic containers. Samples for chemical analyses were chilled on ice and shipped to the NWQL. Samples for grain-size analyses were shipped to the USGS sediment laboratory in Vancouver, Washington.

\section{Laboratory Analyses}

Fish-tissue and bed-sediment samples were analyzed for organochlorine compounds and trace elements by the NWQL. Fish tissue was analyzed for 28 organochlorine compounds, bed sediment for 33 (tables 3 and 4). Compounds analyzed included pesticides, pesticide breakdown products (metabolites), and total PCBs. Compounds were selected for analysis on the basis of factors such as availability of analytical methods, toxicity, bioaccumulation potential, and the capacity of organisms to metabolize the compound (Crawford and Luoma, 1993). Fish tissue was analyzed for 22 trace elements, bed sediment for 38 (tables 3 and 4). Bed-sediment samples also were analyzed for inorganic, organic, and total carbon.

Whole-fish and fillet samples for analyses of organochlorine compounds were composited using a Hobart grinder. Fish-tissue and bed-sediment samples were Soxhlet extracted; lipid was removed by gel per-

Table 3. Organochlorine compounds and trace elements for which fish-tissue samples from the lower Snake River Basin were analyzed, August and September 1997

[MRL, minimum reporting level; for organochlorine compounds, MRL's are in units of micrograms per kilogram, wet weight; for trace elements, MRL's are in units of micrograms per gram, dry weight]

Organochlorine compounds (MRL)

\begin{tabular}{|c|c|}
\hline Aldrin (5) & Beta-HCH (5) \\
\hline cis-chlordane (5) & Delta-HCH (5) \\
\hline trans-chlordane (5) & Gamma-HCH \\
\hline Dacthal (5) & (Lindane) (5) \\
\hline$o, p^{\prime}-\mathrm{DDD}(5)$ & $o, p^{\prime}$-methoxychlor (5) \\
\hline$p, p '-\mathrm{DDD}(5)$ & $p, p$ '-methoxychlor (5) \\
\hline$o, p^{\prime}-\mathrm{DDE}(5)$ & Mirex (5) \\
\hline$p, p$ '-DDE (5) & cis-nonachlor (5) \\
\hline$o, p$ '-DDT (5) & trans-nonachlor (5) \\
\hline$p, p$ '-DDT (5) & Oxychlordane (5) \\
\hline Dieldrin (5) & Polychlorinated \\
\hline Endrin (5) & biphenyls \\
\hline Heptachlor (5) & (total PCBs) (50) \\
\hline Heptachlor epoxide (5) & Pentachloroanisole (5 \\
\hline Hexachlorobenzene (5) & Toxaphene (200) \\
\hline Alpha-HCH (5) & \\
\hline \multicolumn{2}{|c|}{ Trace elements (MRL) } \\
\hline Aluminum (1) & Lead $(0.1)$ \\
\hline Antimony (0.1) & Manganese (0.1) \\
\hline Arsenic $(0.1)$ & Mercury (0.1) \\
\hline Barium (0.1) & Molybdenum (0.1) \\
\hline Beryllium (0.1) & Nickel (0.1) \\
\hline Boron $(0.1)$ & Selenium (0.1) \\
\hline Cadmium (0.1) & Silver $(0.1)$ \\
\hline Chromium (0.5) & Strontium (0.1) \\
\hline Cobalt $(0.1)$ & Uranium (0.1) \\
\hline Copper $(0.5)$ & Vanadium (0.1) \\
\hline Iron (1) & Zinc (0.5) \\
\hline
\end{tabular}


Table 4. Organochlorine compounds, carbon content, and trace elements for which bed-sediment samples from the lower Snake River Basin were analyzed, August and September 1997

[MRL, minimum reporting level for organochlorine compounds and carbon, in micrograms per kilogram and grams per kilogram, dry weight, respectively; LLD, lower level of determination for trace elements, in micrograms per gram, dry weight, unless presented as a percent]

\begin{tabular}{|c|c|}
\hline \multicolumn{2}{|c|}{ Organochlorine compounds (MRL) } \\
\hline Aldrin (1) & Beta-HCH (1) \\
\hline cis-chlordane (1) & Delta-HCH (1) \\
\hline trans-chlordane (1) & Gamma-HCH \\
\hline Chloroneb (5) & (Lindane) (1) \\
\hline $\operatorname{DCPA}(5)$ & Isodrin (1) \\
\hline$o, p^{\prime}$-DDD (1) & $o, p$ '-methoxychlor (5) \\
\hline$p, p$-DDD (1) & $p, p$-methoxychlor (5) \\
\hline$o, p$-DDE (1) & Mirex (1) \\
\hline$p, p$-DDE (1) & cis-nonachlor (1) \\
\hline$o, p$-DDT (2) & trans-nonachlor (1) \\
\hline$p, p '-\mathrm{DDT}(2)$ & Oxychlordane (1) \\
\hline Dieldrin (1) & Pentachloroanisole (1) \\
\hline Endosulfan (1) & cis-permethrin (5) \\
\hline Endrin (2) & trans-permethrin (5) \\
\hline Heptachlor (1) & Polychlorinated \\
\hline Heptachlor epoxide (1) & biphenyls \\
\hline Hexachlorobenzene (1) & (total PCBs) (50) \\
\hline Alpha-HCH (1) & Toxaphene (200) \\
\hline \multicolumn{2}{|c|}{ Carbon (MRL) } \\
\hline Inorganic carbon $(0.1)$ & Total carbon $(0.1)$ \\
\hline Organic carbon $(0.1)$ & \\
\hline \multicolumn{2}{|c|}{ Trace elements (LLD) } \\
\hline Aluminum $(0.05 \%)$ & Manganese (4) \\
\hline Antimony $(0.1)$ & Mercury $(0.02)$ \\
\hline Arsenic $(0.1)$ & Molybdenum (2) \\
\hline Barium (1) & Neodymium (4) \\
\hline Beryllium (1) & Nickel (2) \\
\hline Bismuth (10) & Niobium (4) \\
\hline Cadmium (0.1) & Scandium (2) \\
\hline Cerium (4) & Selenium $(0.1)$ \\
\hline Chromium (1) & Silver $(0.1)$ \\
\hline Cobalt (1) & Strontium (2) \\
\hline Copper (1) & Tantalum (40) \\
\hline Europium (2) & Thorium (4) \\
\hline Gallium (4) & $\operatorname{Tin}(5)$ \\
\hline Gold (8) & Titanium $(0.005 \%)$ \\
\hline Holmium (4) & Uranium (0.05) \\
\hline Iron $(0.05 \%)$ & Vanadium (2) \\
\hline Lanthanum (2) & Ytterbium (1) \\
\hline Lead (4) & Yttrium (2) \\
\hline Lithium (2) & Zinc (4) \\
\hline
\end{tabular}

meation chromatography and fractionated using alumina/silica adsorption chromatography. The extracts were analyzed by dual capillary-column gas chromatography with electron-capture detection. Percent lipid in fish tissue was determined using a methylene chloride extract. Detailed descriptions of the methods used for analysis of organochlorine compounds in fish tissue and bed sediment are in reports by Leiker and others (1995) and Foreman and others (1995), respectively.
Fish-tissue samples were prepared for trace-element analyses by low-temperature nitric acid digestion followed by the addition of hydrogen peroxide to decompose biological material. Bed-sediment samples for trace-element analyses were digested using a mixture of hydrochloric, nitric, perchloric, and hydrofluoric acids. The resultant solutions from tissue and bed sediment were evaporated to dryness, reconstituted with 5 percent nitric acid, and filtered. Fish-tissue extracts were analyzed by inductively coupled plasma-mass spectrometry, inductively coupled plasma-atomic emission spectrometry (ICP-AES), and cold vapor-atomic absorption spectrophotometry. Bed-sediment extracts were analyzed by ICP-AES. Detailed descriptions of the methods used for analyses of trace elements in fish tissue and bed sediment are contained in reports by Hoffman (1996) and Arbogast (1990), respectively.

\section{ORGANOCHLORINE COMPOUNDS}

The use of organochlorine compounds in the United States began in the 1940's; usage peaked during the late 1950's and early 1960's (Larson and others, 1997). Use of most organochlorine compounds was discontinued during the 1970's and 1980's because of their adverse ecological effects. However, the presence of organochlorine compounds in aquatic systems is still a concern because of their toxicity, their classification as probable human carcinogens (Nowell and Resek, 1994), and their possible link to endocrine disruption in fish and other wildlife (Colborn and others, 1993; Goodbred and others, 1997).

In general, organochlorine compounds are extremely hydrophobic (water insoluble) and have long environmental lifetimes (Larson and others, 1997). Because of their resistance to breakdown, organochlorine compounds can accumulate in animal tissue, where they can remain at detectable levels for years (Larson and others, 1997). The U.S. Environmental Protection Agency (USEPA) detected concentrations of DDT and PCBs in fish tissue at 98 and 90 percent of 399 sites, respectively, throughout the Nation during 1986-89 (U.S. Environmental Protection Agency, 1992).

\section{Fish Tissue}

Fish tissue analyzed during this study contained detectable concentrations of 12 different organochlorine compounds or metabolites, and bed sediment con- 
tained 5. All fish-tissue and bed-sediment samples contained DDT and(or) one of its metabolites; 6 of 8 wholebody samples (excluding the QA sample) contained total DDT concentrations that exceeded the 85th percentile value of $175 \mu \mathrm{g} / \mathrm{kg}$ as detected in 218 samples collected nationwide as part of the NAWQA Program during 1992-94 (Lisa Nowell, U.S. Geological Survey, written commun., 1998). Concentrations of total DDT in the 14 fish-tissue samples ranged from $11 \mu \mathrm{g} / \mathrm{kg}$ in fillets of yellow perch (Perca flavescens) from C.J. Strike Reservoir to $3,633 \mu \mathrm{g} / \mathrm{kg}$ in a whole-body sample of carp from Brownlee Reservoir at the Burnt River site (fig. 2). Total DDT concentrations in whole-body samples of suckers and carp from Brownlee Reservoir at Burnt River and in whole-body samples of suckers from the Snake River at C.J. Strike Reservoir, Snake River at Swan Falls, and Snake River at Nyssa exceeded the criteria of $200 \mu \mathrm{g} / \mathrm{kg}$ established by the New York Department of Environmental Conservation (NYDEC) for the protection of fish-eating wildlife (Newell and others, 1987). Total PCB concentrations also exceeded the NYDEC fish-eating wildlife criteria of $110 \mu \mathrm{g} / \mathrm{kg}$ in a whole-body sample of carp from Brownlee Reservoir at Burnt River (fig. 2). The concentration of total DDT $(3,633 \mu \mathrm{g} / \mathrm{kg})$ in the carp sample from the Burnt River site exceeded all the fish-tissue concentrations detected during the upper Snake River Basin NAWQA study or the 1990 DOI study. However, whole-body samples of channel catfish (Ictalurus punctatus) collected from Brownlee Reservoir during the DOI study contained concentrations of dieldrin and toxaphene larger than concentrations in all the fish-tissue samples collected during this study.

Concentrations of organochlorine compounds in whole-body samples were, in general, larger than concentrations in sportfish fillets. However, concentrations of dieldrin and total DDT in fillets of channel catfish from the Snake River at Nyssa and Brownlee Reservoir at Burnt River, and total DDT in fillets of smallmouth bass (Micropterus dolomieui) and white crappie (Pomoxis annularis) from Brownlee Reservoir at Burnt River exceeded a cancer risk screening value of $10^{-6}$ established by the USEPA (Nowell and Resek, 1994) (fig. 2). A $10^{-6}$ screening value indicates an increased risk of cancer for one person per million people with a body weight of 70 kilograms (154 pounds) eating 6.5 grams ( 0.23 ounces) of fish per day for 70 years. None of the organochlorine compound concentrations in fillet samples, however, exceeded FDA action levels for human consumption of fish (Nowell and Resek, 1994).

The smallest concentration of total DDT in a wholebody sample $(39 \mu \mathrm{g} / \mathrm{kg})$ was in suckers from the Salmon River at White Bird (fig. 2). Although the concentration of total DDT in the Salmon River sample was slightly larger than the nationwide baseline concentration of $29 \mu \mathrm{g} / \mathrm{kg}$ reported by Schmitt and others (1990), it was smaller than the geometric mean concentration of $60 \mu \mathrm{g} / \mathrm{kg}$ present in six sucker samples collected from the Salmon River near Riggins during the late 1970's and early 1980's (Schmitt and others, 1990). The historical Salmon River sucker samples also contained detectable concentrations of chlordane, heptachlor, nonachlor, and PCBs (Schmitt and others, 1990). None of these compounds were detected in the wholebody sample of suckers collected from the Salmon River during this study.

Fish-tissue data collected during this study, combined with data from the upper Snake River Basin NAWQA study (fig. 3 and table 5) indicate that concentrations of organochlorine compounds in whole-body samples of suckers, in general, increase from the headwaters of the Snake River near Flagg Ranch in Wyoming downstream to Brownlee Reservoir (fig. 4). The increase is probably attributable to the large amount of agricultural activity along the Snake River and its tributaries from Idaho Falls to Brownlee Reservoir. Most of the fine-grained sediment and associated organochlorine compounds transported in the Snake River probably are trapped in Brownlee Reservoir. As a result, concentrations of organochlorine compounds in the suckers from the Snake River at Pittsburg Landing are much smaller than concentrations in suckers from Brownlee Reservoir. Using upper Snake River Basin NAWQA data, Maret and Ott (1997) determined a direct relationship $\left(\mathrm{r}^{2}=0.48\right)$ between DDT concentrations in fish-tissue samples and the amount of agricultural land in the upstream drainage area. Although fishtissue samples from several headwater sites in the NAWQA study contained detectable concentrations of DDT and(or) its metabolites, these concentrations were, in general, at least an order of magnitude smaller than concentrations in tissue samples from sites downstream from agricultural and other human activities (Maret and Ott, 1997). 


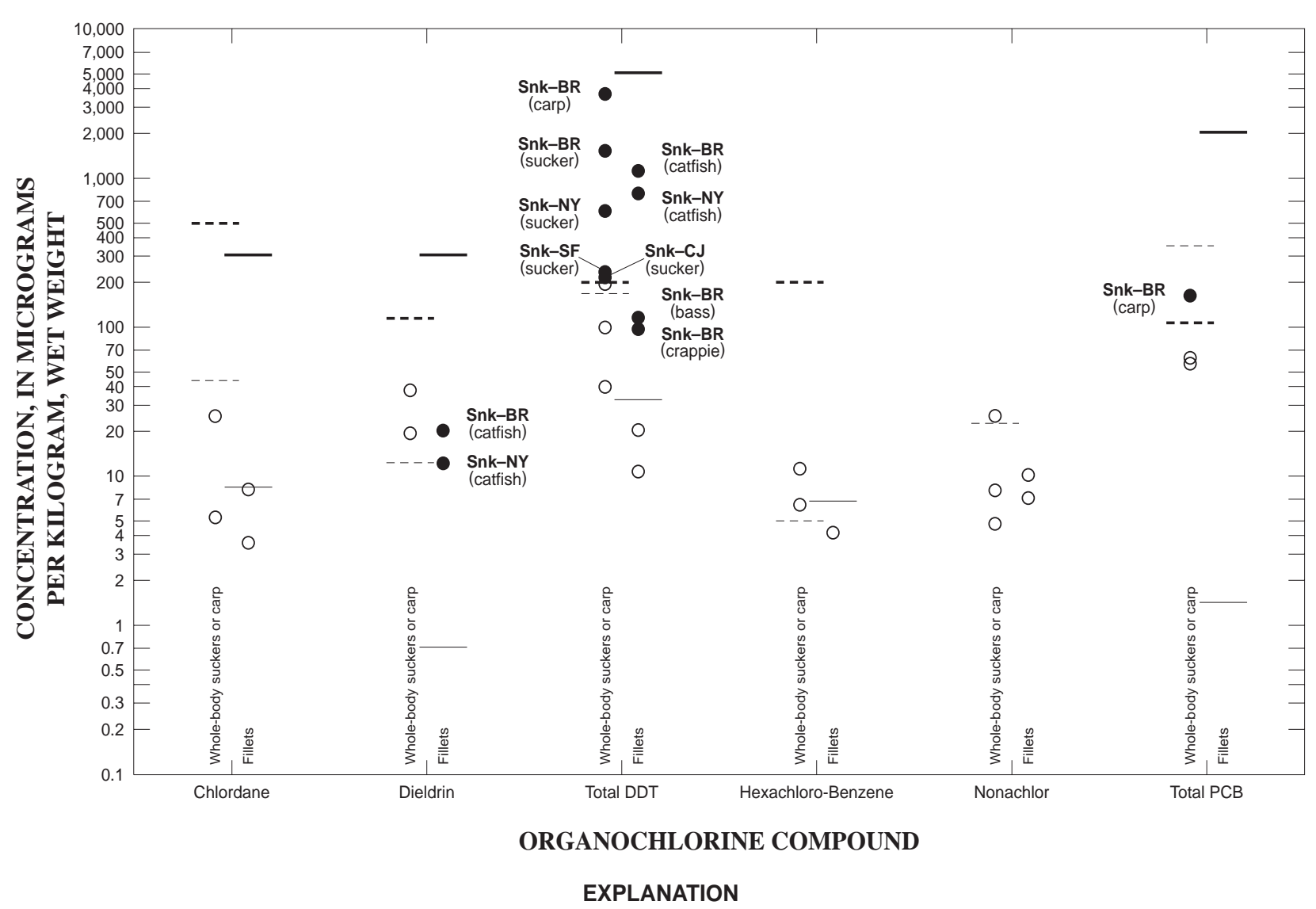

U.S. Environmental Protection Agency (EPA) screening level of $10^{-6}$ for contaminants in edible fish (Nowell and Resek, 1994)

85th percentile value for whole-body fish samples collected nationwide by the U.S. Geological Survey National WaterQuality Assessment (NAWQA) Program, 1992-94 (Lisa Nowell, U.S. Geological Survey, written commun., 1998)

- - - - New York State/Department of Environmental Conservation (NYDEC) criteria for protection of fish-eating wildlife (Newell and others, 1987)
U.S. Food and Drug Administration (FDA) action level for contaminant in edible fish (Nowell and Resek, 1994)

- Detection exceeds EPA screening level or NYDEC criteria

O Detection less than EPA screening level or NYDEC criteria

Snk-BR Site identification and type of fish-Site locations shown (crappie) in figure 1; site identifications listed in table 1

Figure 2. Concentrations of selected organochlorine compounds in fish-tissue samples from the lower Snake River Basin, August and September 1997.

\section{Bed Sediment}

Concentrations of organochlorine compounds in the bed-sediment samples collected during this study were smaller than those in fish-tissue samples. Concentrations of p,p'DDE, the only compound detected in all the bed-sediment samples, ranged from $1.1 \mu \mathrm{g} / \mathrm{kg}$ in the sample from C.J. Strike Reservoir to $11 \mu \mathrm{g} / \mathrm{kg}$ in the sample from Brownlee Reservoir at the Burnt River site. The only organochlorine compound with a concentration that exceeded the PEL established for the protection of benthic life (Canadian Council of Ministers of the Environment, 1995) was p,p'DDE in the sample from the Burnt River site.

Although both sites are in Brownlee Reservoir, the number of organochlorine compounds and their concentrations in bed sediment from the Burnt River site exceeded those in bed sediment from the Mountain Man Lodge site about 15 mi farther downstream (fig. 3). Much of the suspended sediment transported in the Snake River is clay sized (less than 63 micrometers in diameter). On entering Brownlee Reservoir, the river 


\section{EXPLANATION}

Sample site-Site identifications

Snk-BR listed in tables 1 and 5

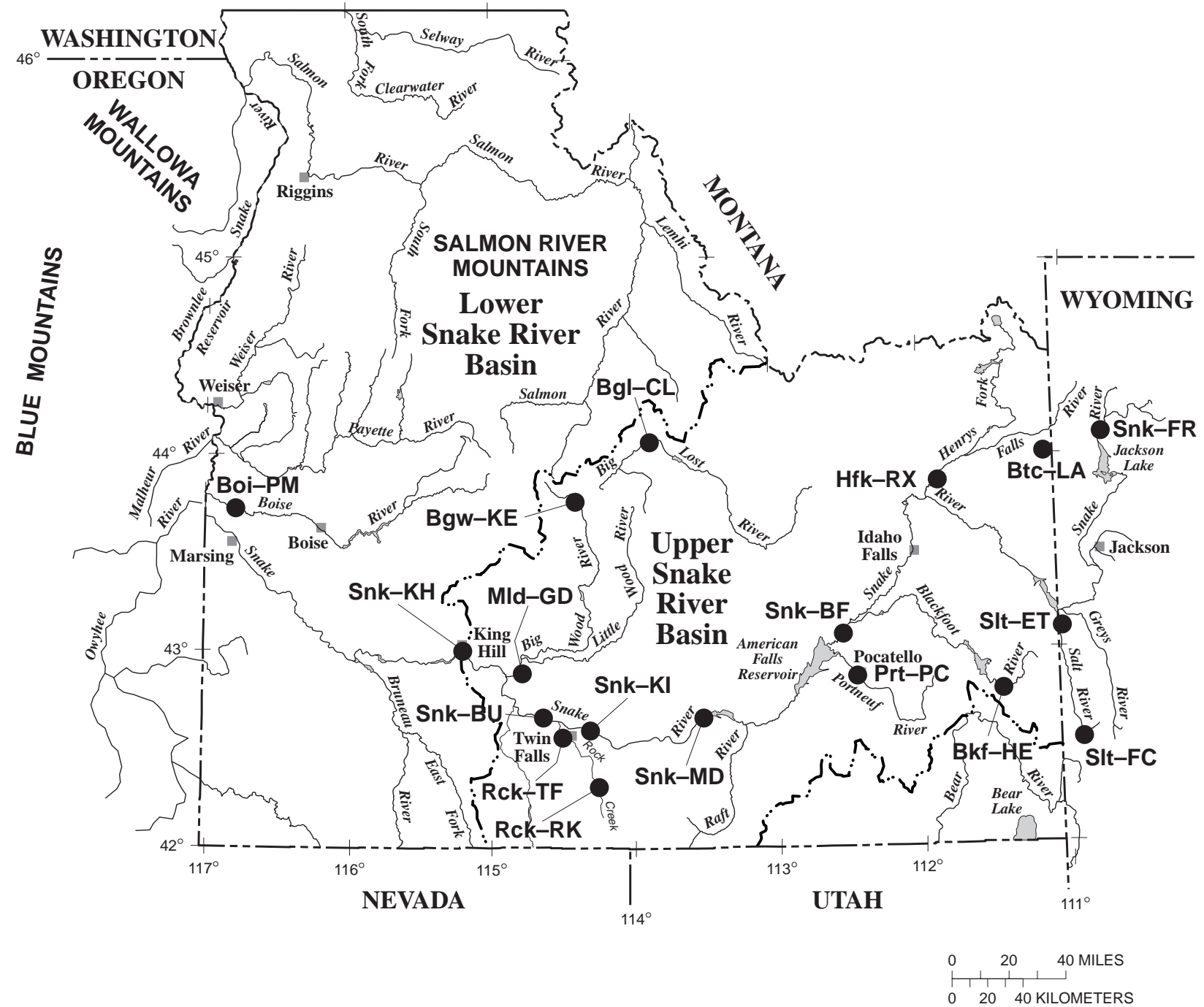

Figure 3. Additional sites in the Snake River Basin where fish-tissue and(or) bed-sediment samples were collected for analysis of organochlorine compounds and(or) trace elements, 1992-97. 
Table 5. Additional sites in the Snake River Basin where fish-tissue and bed-sediment samples were collected and analyzed for organochlorine compounds and trace elements, 1992-97

[Sample sites are shown in figure 3; all sites are in Idaho unless otherwise noted; WY, Wyoming; - , not sampled]

\begin{tabular}{llccc}
\hline $\begin{array}{c}\text { Site } \\
\text { identi- } \\
\text { fication }\end{array}$ & \multicolumn{1}{c}{ Site name } & $\begin{array}{c}\text { Whole-body suckers, } \\
\text { organochlorine } \\
\text { compounds }\end{array}$ & $\begin{array}{c}\text { Body parts } \\
\text { analyzed, } \\
\text { trace } \\
\text { elements }\end{array}$ & $\begin{array}{c}\text { Bed sediment, } \\
\text { organochlorine compounds } \\
\text { and trace elements }\end{array}$ \\
\hline Snk-FR & Snake River at Flagg Ranch, WY & 1995 & - & 1995 \\
Sit-FC & Salt River near Fish Creek, WY & 1993 & - & 1993 \\
Slt-ET & Salt River near Etna, WY & 1994 & 1994 \\
Btc-LA & Bitch Creek near Lamont & 1993 & 1993 \\
Hfk-RX & Henrys Fork near Rexburg & 1996 & 1996 \\
Bkt-HE & Blackfoot River near Henry & 1992 & 1996 & 1992 \\
Snk-BF & Snake River near Blackfoot & 1996 & 1996 & 1992 \\
Prt-PC & Portnuef River at Pocatello & 1996 & 1992 & 1993 \\
Snk-MD & Snake River near Minidoka & 1993 & 1992 \\
Snk-KI & Snake River near Kimberly & 1992 & - & 1993 \\
Rck-RK & Rock Creek near Rock Creek & 1993 & 1997 \\
Rck-TF & Rock Creek at Twin Falls & 1996 & 1996 & 1994 \\
Snk-BU & Snake River near Buhl & 1996 & - & 1993 \\
Bgl-CL & Big Lost River near Chilly & 1994 & - & 1993 \\
Bgw-KE & Big Wood River near Ketchum & 1993 & - & 1997 \\
Mld-GD & Malad River near Gooding & 1993 & 1997 & - \\
Snk-KH & Snake River at King Hill & 1997 & 1996 & \\
Boi-PM & Boise River near Parma & 1996 & & \\
\hline
\end{tabular}

loses velocity and suspended sediment settles to the channel bottom. The settling of suspended sediment results in the accumulation of fine-grained bed sediment in the upstream end of Brownlee Reservoir near the Burnt River site. As a result, the sample from the Burnt River site contained a larger proportion of claysized material (30 percent) and associated organic carbon (21 percent) than the sample from the Mountain Man Lodge site (7 and 9.5 percent, respectively). Because organochlorine compounds accumulate in finegrained, organic-rich bed sediment, concentrations at the Burnt River site are larger than those farther downstream in the reservoir.

Data from this study, combined with data from the upper Snake River Basin NAWQA study, indicate that organochlorine concentrations in bed sediment, as in fish tissue, generally increase from the headwaters of the Snake River near Flagg Ranch, Wyoming, downstream to Brownlee Reservoir (fig. 5). Three of 9 bedsediment samples from the main stem of the Snake River and 8 of 11 bed-sediment samples from Snake River tributaries contained no detectable concentrations of organochlorine compounds. Of all the bed-sediment samples collected in the Snake River Basin from 1992 to 1997, the sample from Brownlee Reservoir at Burnt River contained the largest concentration of total orga- nochlorine compounds. Of all the samples from Snake River tributary sites, samples from the Portneuf River at Pocatello and Rock Creek at Twin Falls contained the largest organochlorine concentrations. As in the fish-tissue samples, DDT and its metabolites were the predominant organochlorine compounds in bed sediment.

\section{TRACE ELEMENTS}

Unlike their relatively recent exposure to organochlorine compounds, aquatic organisms have always been exposed to trace elements. As a result, many aquatic organisms have developed mechanisms either to control the internal concentrations of certain trace elements or to mitigate their toxic effects (Law, 1996). Many trace elements are essential for the health and growth of aquatic organisms. However, as a result of their chemical reactivity, all trace elements, whether essential or not, have the potential to be toxic when ingested in excessive amounts. As with organochlorine compounds, trace-element concentrations are generally higher in bed sediments and fish tissue than in water (Rainbow, 1996). Some of the more toxic trace elements, including cadmium, lead, and mercury, bioaccu- 


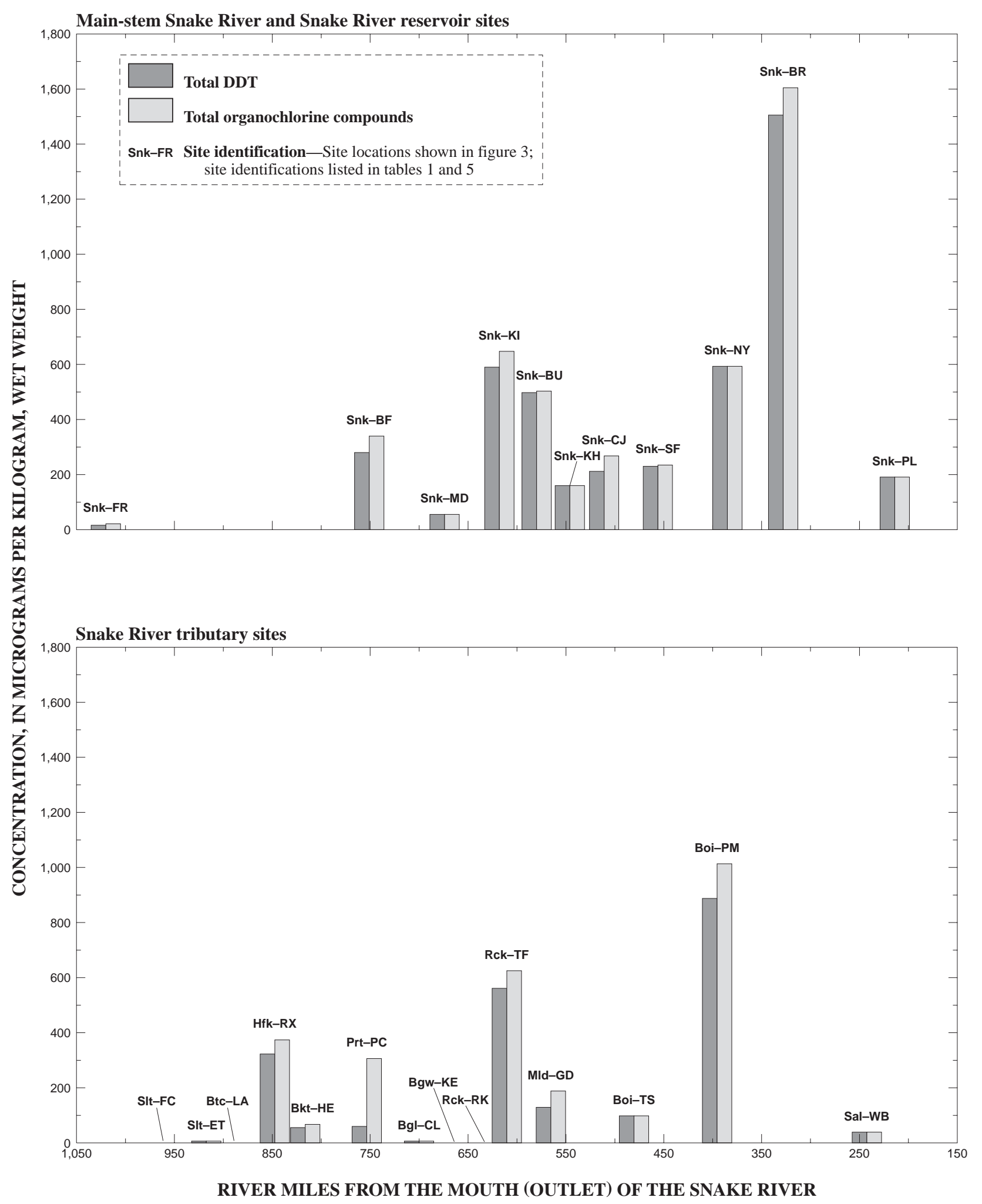

Figure 4. Concentrations of total DDT and total organochlorine compounds in suckers from the Snake River, Snake River reservoirs, and Snake River tributaries, 1992-97. 


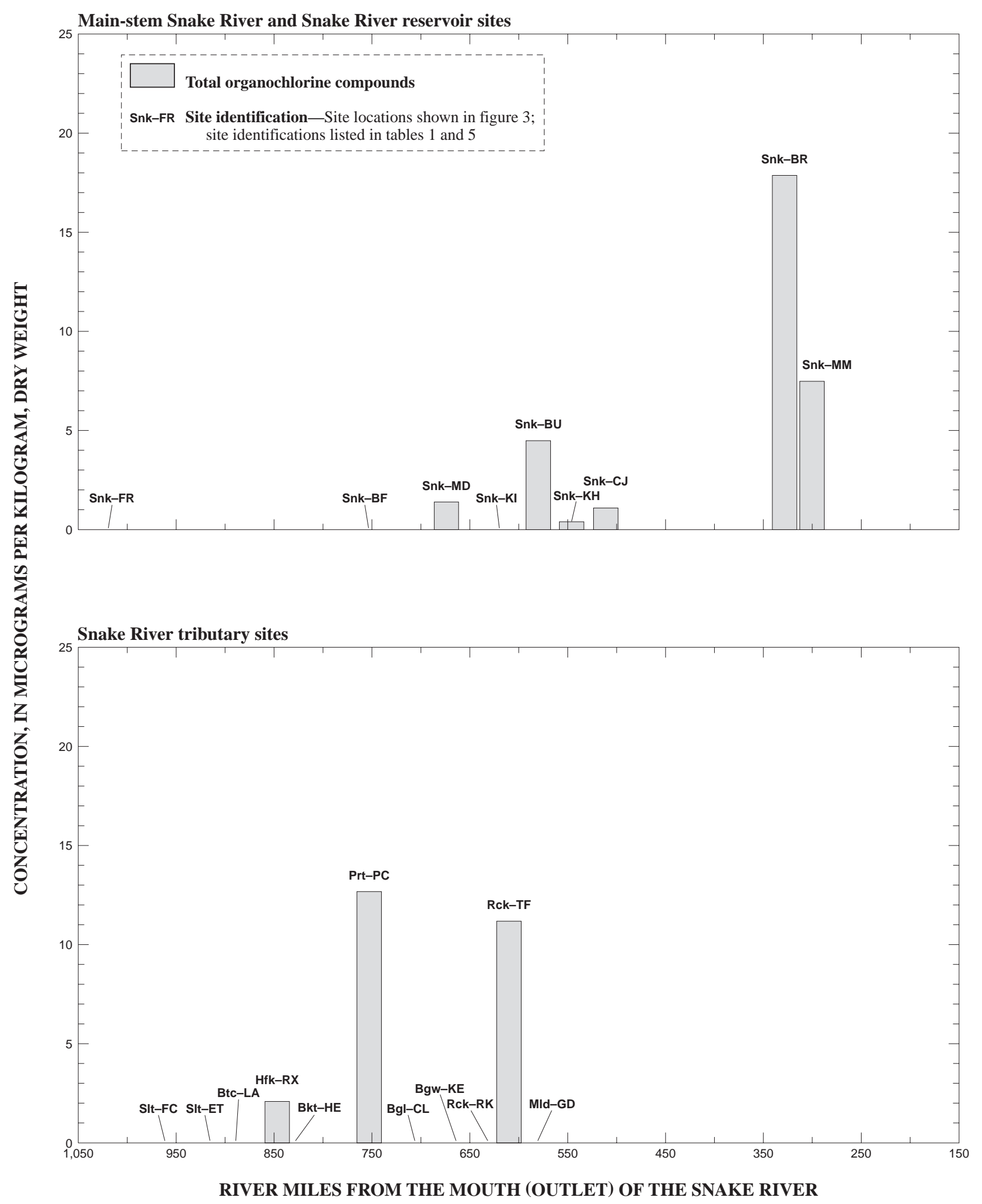

Figure 5. Concentrations of total organochlorine compounds in bed sediment from the Snake River, Snake River reservoirs, and Snake River tributaries, 1992-97. 
mulate in aquatic food chains because of a slow rate of elimination. As a result, trace-element concentrations in tissues of aquatic organisms generally increase as the organisms age and increase in body size (Wiener and Spry, 1996).

\section{Fish Tissue}

Of the fish-tissue samples from the lower Snake River Basin, the liver sample from carp from Brownlee Reservoir at Burnt River and the liver sample from suckers from the Boise River near Twin Springs contained the largest trace-element concentrations (fig. 6). Concentrations of cadmium, copper, and zinc in the liver samples from these sites, and from the Salmon River at White Bird (fig. 6), were above or near the 85th percentile values (California EDL 85) for liver samples from fish collected in California during 1978 95 (California State Water Resources Control Board, written commun., 1996). The liver samples from the Boise River near Twin Springs and the Salmon River at White Bird were the only tissue samples collected during the study with detectable concentrations of lead; the concentration in the sample from the Boise River near Twin Springs exceeded the California EDL 85.

None of the trace-element concentrations in fillets of sportfish collected during this study (fig. 6) exceeded the median international standard for edible fish tissue (Nauen, 1983). In general, concentrations of most trace

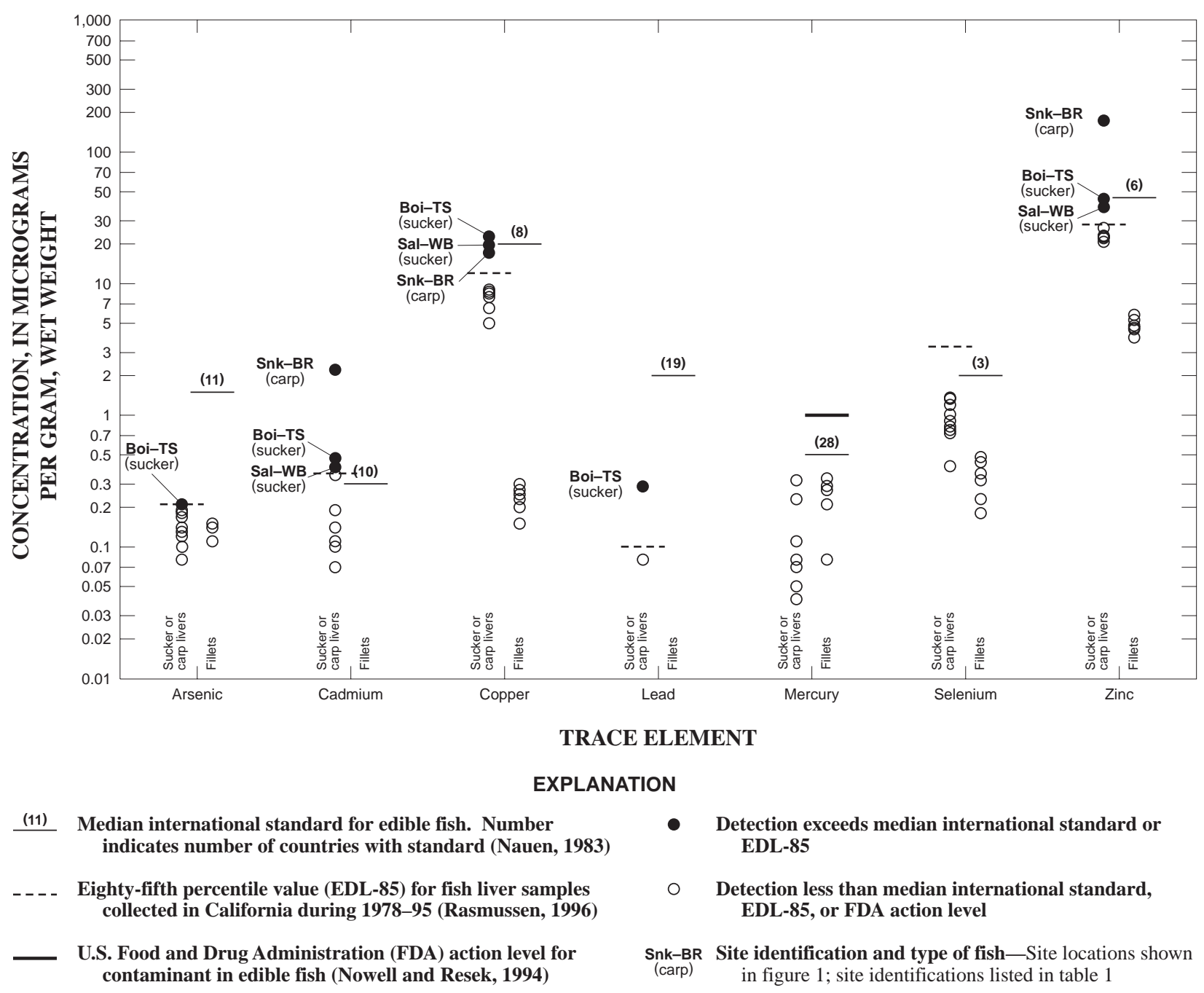

Figure 6. Concentrations of selected trace elements in fish-tissue samples from the lower Snake River Basin, August and September 1997. 


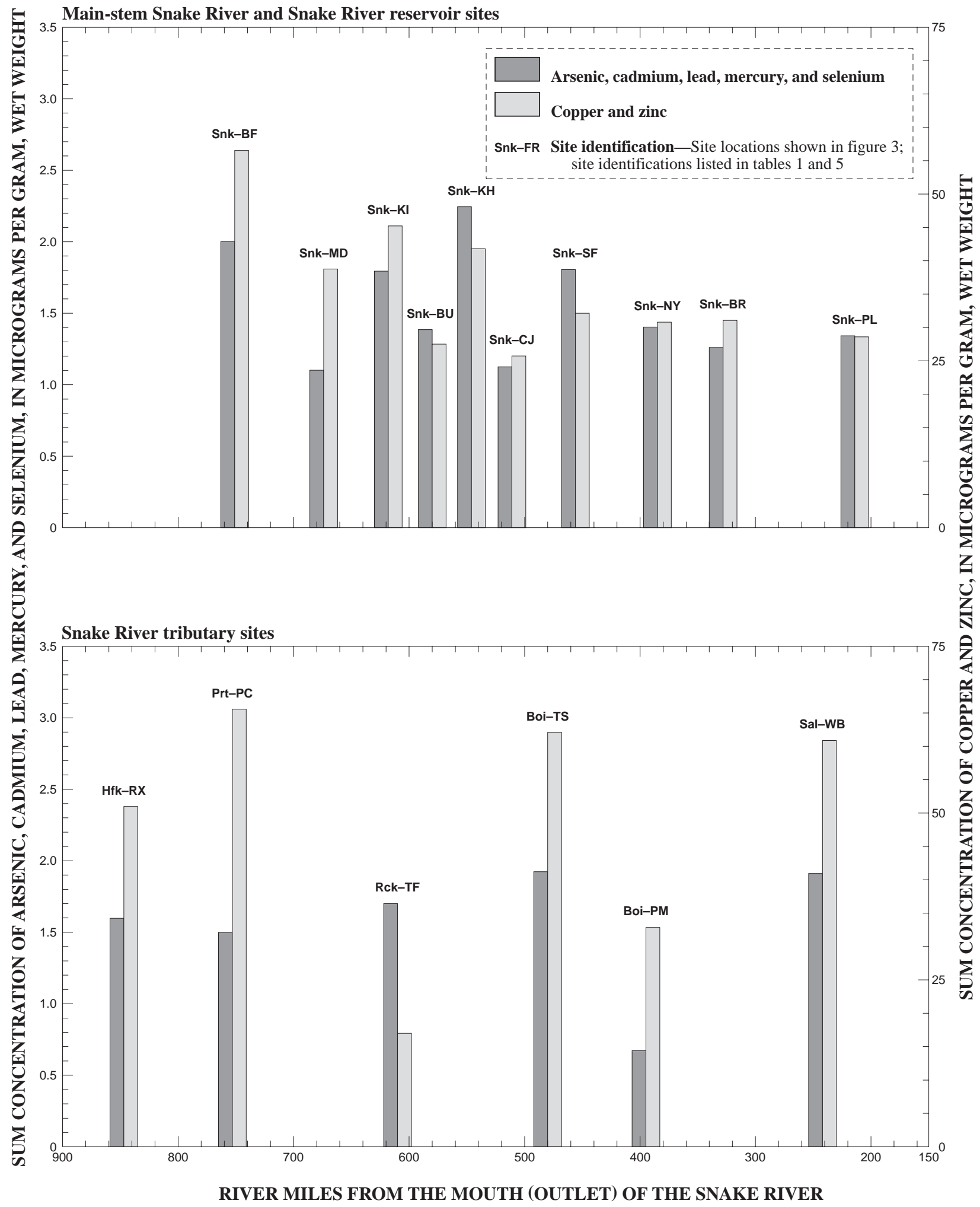

Figure 7. Sum concentrations of selected trace elements in liver samples of suckers from the Snake River Basin, 1992-97. 


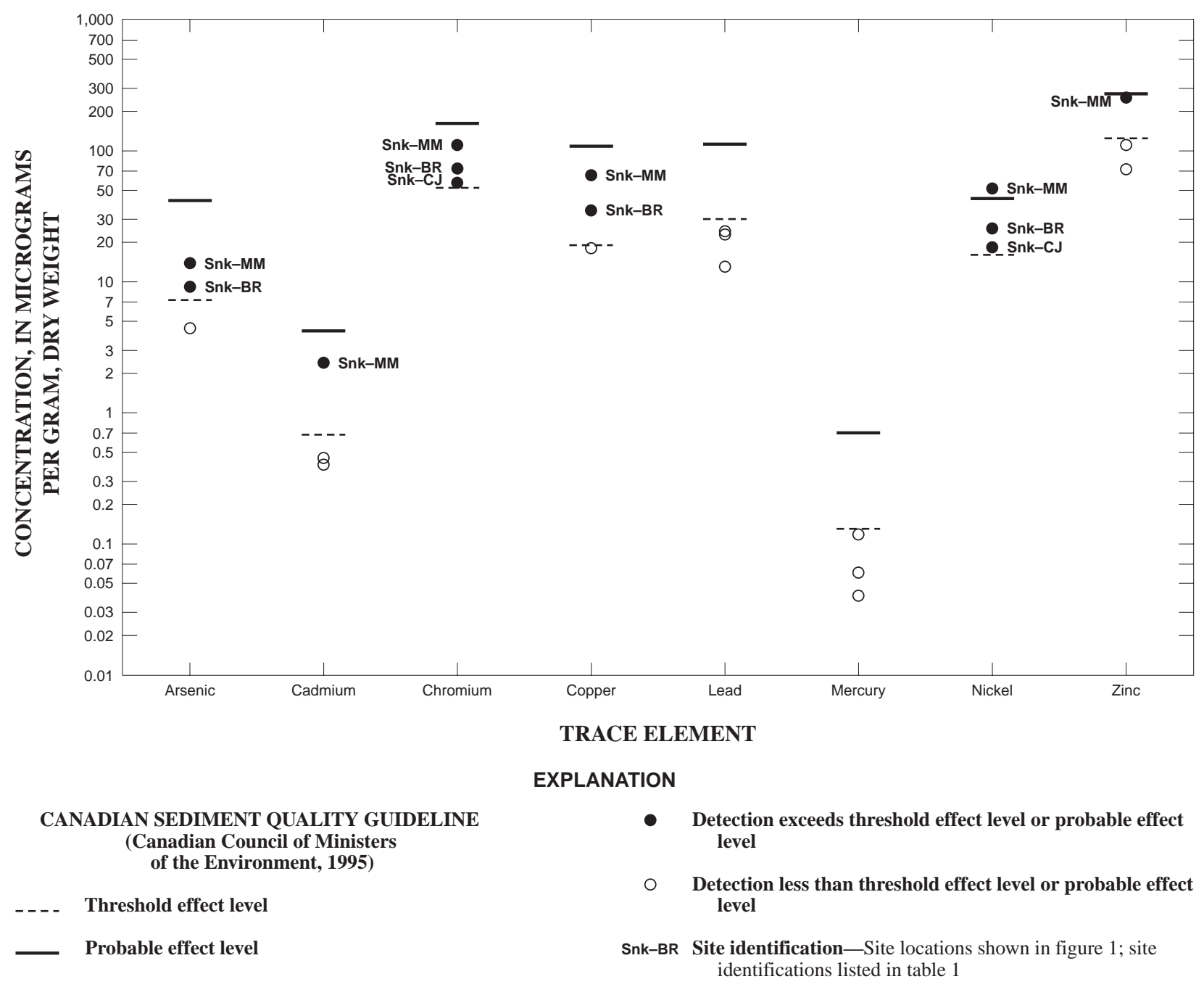

Figure 8. Concentrations of selected trace elements in bed-sediment samples from the lower Snake River Basin, August 1997.

elements were larger in liver samples than in sportfish fillets. However, mercury concentrations were generally larger in the sportfish fillets, ranging from $0.08 \mu \mathrm{g} / \mathrm{g}$ in yellow perch from C.J. Strike Reservoir to $0.32 \mu \mathrm{g} / \mathrm{g}$ in channel catfish from Brownlee Reservoir at Burnt River. Because mercury, primarily in the toxic methylmercury form, accumulates in muscle tissue (Goldstein and others, 1996; Wiener and Spry, 1996), mercury can be hazardous to human health (Erwin and Munn, 1997). However, none of the mercury concentrations in fillet samples exceeded either the median international standard of $0.5 \mu \mathrm{g} / \mathrm{g}$ or the FDA action level of $1.0 \mu \mathrm{g} / \mathrm{g}$ for mercury in edible fish tissue. In general, mercury concentrations in fish-tissue samples collected during this study were smaller than those in fish-tissue samples collected at comparable sites during previous studies in the lower Snake River Basin (Rinella and others, 1994; Ken Kauffman, Oregon Department of Environmental Quality, written commun., 1997; Brian Abbott, Idaho Department of Health and Welfare, written commun., 1997).

A comparison of data from the upper Snake River Basin NAWQA study with data collected during this study indicates that, unlike organochlorine compounds, concentrations of trace elements in liver samples from the main stem of the Snake River and Snake River reservoirs tend to decrease in a downstream direction (fig. 7). Some of the largest trace-element concentrations in the Snake River Basin were detected in liver samples from tributary streams, primarily the Portneuf River at Pocatello, Boise River near Twin Springs, and Salmon River near White Bird. Elevated trace-element concen- 


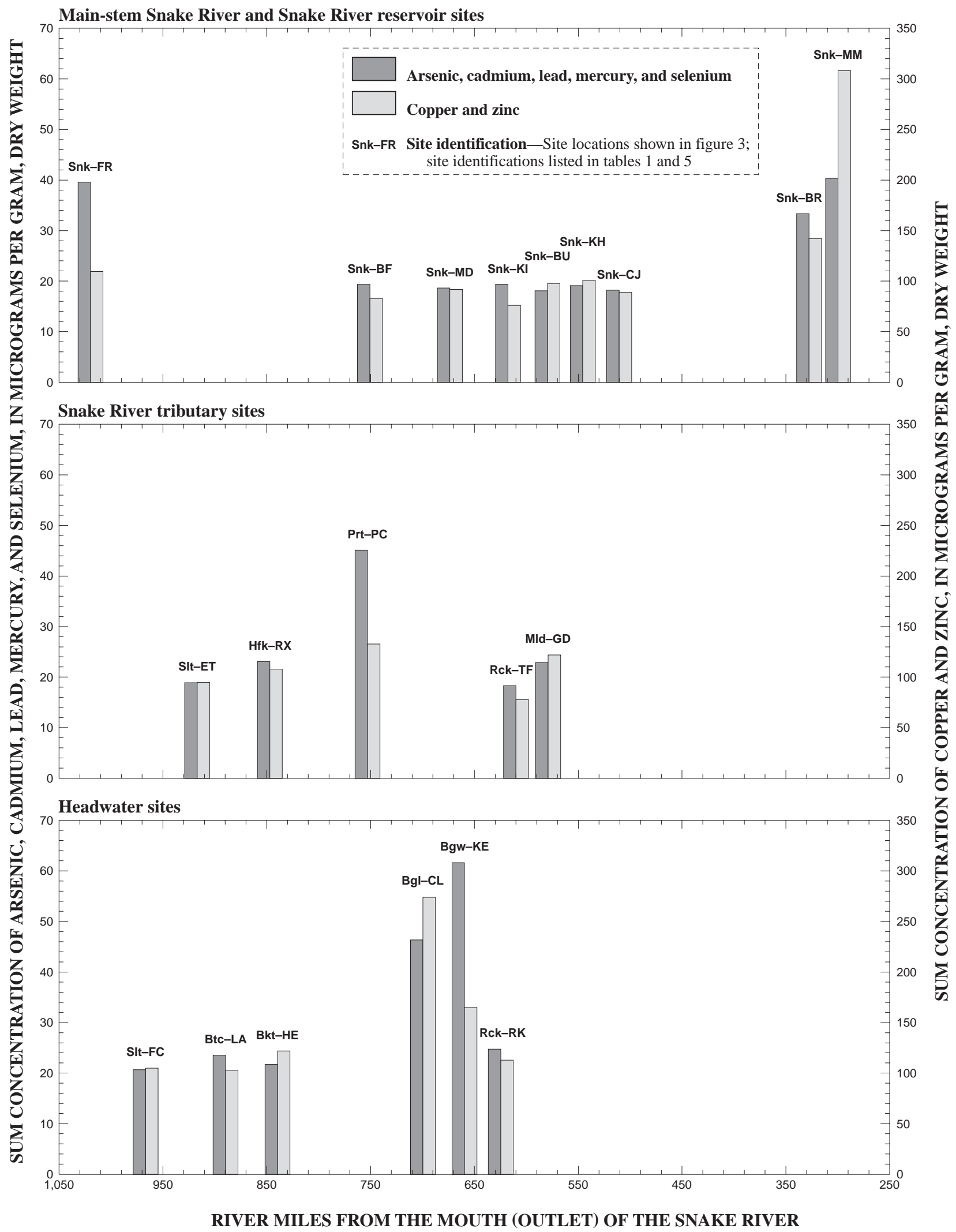

Figure 9. Sum concentrations of selected trace elements in bed-sediment samples from the Snake River Basin, 1992-97. 
trations in liver samples from the Portneuf River at Pocatello are probably a result of industrial activities in and near the city of Pocatello. In contrast, the elevated trace-element concentrations in the liver samples from the Boise and Salmon Rivers are probably a result of historical mining and weathering of metal-rich rocks.

\section{Bed Sediment}

Of the three bed-sediment samples collected during this study, the sample from Brownlee Reservoir at Mountain Man Lodge contained the largest concentrations of most trace elements (fig. 8). Concentrations of arsenic, cadmium, chromium, copper, nickel, and zinc in bed sediment from the Mountain Man Lodge site exceeded either the threshold effect level (TEL) or PEL established by the Canadian Council of Ministers of the Environment (1995) for the protection of benthic life. Arsenic, chromium, copper, and nickel concentrations in bed sediment from the Burnt River site, and chromium, copper, and nickel in bed sediment from C.J. Strike Reservoir also exceeded the TEL. Bed-sediment concentrations of lead and mercury were less than the TEL and PEL at all sites.

Comparison of upper Snake River Basin NAWQA bed-sediment data with data from the three samples from the lower Snake River Basin indicates that concentrations of several trace elements in bed sediment from the Mountain Man Lodge site were the largest in the Snake River Basin (fig. 9). Large concentrations of trace elements also were present in bed sediment from the Snake River at Flagg Ranch, Portneuf River at Pocatello, Big Lost River near Chilly, and Big Wood River near Ketchum. Whereas the Portneuf River at Pocatello site probably is affected by industrial activities, the Snake River at Flagg Ranch, Big Lost River near Chilly, and Big Wood River near Ketchum are all headwater sites. These sites all contained bed sediment enriched with arsenic, lead, and zinc, probably the result of historical mining and weathering of metal-rich rocks. Compared with bed-sediment samples from other NAWQA sites across the Nation, the samples from the Big Lost and Big Wood Rivers contained some of the largest concentrations of trace elements (Clark and others, 1998). The trace-element concentrations in the sample from the Mountain Man Lodge site also would rank as highly enriched on a national scale.

\section{SUMMARY}

Data collected during this study indicate that concentrations of organochlorine compounds and trace elements in fish tissue and bed sediment in the lower Snake River Basin may pose a health risk to humans and(or) wildlife. Although concentrations of organochlorine compounds and trace elements in fish fillets did not exceed FDA action levels or median international standards, concentrations of some organochlorine compounds in fish fillets exceeded cancer risk screening values of $10^{-6}$, established by the USEPA for human consumption of fish. Concentrations of some organochlorine compounds in whole-body samples of fish and concentrations of some trace elements in fish livers exceeded criteria established for the protection of fish-eating wildlife. Some bed-sediment samples also contained organochlorine compounds and trace elements at concentrations that exceeded guidelines for the protection of benthic life.

Concentrations of organochlorine compounds in fish tissue and bed sediment generally were larger in samples from downstream parts of the Snake River Basin. Whole-body samples of fish from Brownlee Reservoir at Burnt River contained the largest concentrations of organochlorine compounds in the basin. Compared with concentrations in samples collected across the Nation during 1992-94 as part of the U.S. Geological Survey's National Water-Quality Assessment Program, concentrations of dieldrin and total DDT in suckers and carp from Brownlee Reservoir were among the largest. Bed sediment from Brownlee Reservoir at Burnt River contained the largest concentrations of organochlorine compounds in the Snake River Basin. However, only p,p'DDE in bed sediment at the Burnt River site exceeded a sediment quality Probable Effect Level established by the Canadian Government for the protection of benthic life.

In contrast to organochlorine compounds, concentrations of trace elements in fish tissue and bed sediment were generally smaller in the lower Snake River Basin than in the upper Snake River Basin. Concentrations of most trace elements were larger in liver samples from largescale suckers and common carp than in sportfish fillets; mercury concentrations were generally larger in the sportfish fillets. Sportfish fillets from Brownlee Reservoir at Burnt River contained the largest concentrations of mercury. However, none of the mercury concentrations in fillets exceeded the median international standard or the FDA action level. Mercury 
concentrations in samples analyzed during this study were generally smaller than concentrations in samples analyzed during previous investigations of the lower Snake River Basin. Concentrations of several trace elements in bed sediment from the Mountain Man Lodge site in Brownlee Reservoir were the largest in the Snake River Basin.

\section{REFERENCES CITED}

Arbogast, B.F., ed., 1990, Quality assurance manual for the Branch of Geochemistry, U.S. Geological Survey: U.S. Geological Survey Open-File Report 90-668, $184 \mathrm{p}$.

Blus, L.J., 1996, DDT, DDD, and DDE in birds, in Beyer, W.N., Heinz, G.H., and Redmon-Norwood, A.W., eds., Environmental contaminants in wildlife: Boca Raton, Fla., CRC Press, Inc., p. 49-71.

Brennan, T.S., Lehmann, A.K., O’Dell, I., and Tungate, A.M., 1997, Water resources data, Idaho, water year 1996: U.S. Geological Survey Water-Data Report ID-96-2, $377 \mathrm{p}$.

Buhler, D.R., Claeys, R.R., and Shanks, W.E., 1973, Mercury in aquatic species from the Pacific Northwest, in Buhler, D.R., ed., Proceedings of the workshop on mercury in the Western environment: Corvallis, Oreg., Oregon State University Continuing Education, p. 59-75.

Canadian Council of Ministers of the Environment, 1995, Protocol for the derivation of Canadian sediment quality guidelines for the protection of aquatic life: Report CCME EPC-98E, March 1995 [variously paged].

Clark, G.M., Maret, T.R., Rupert, M.G., Maupin, M.A., Low, W.H., and Ott, D.S., 1998, Water quality in the upper Snake River Basin, Idaho and Wyoming, 1992-1995: U.S. Geological Survey Circular 1160, 35 p.

Colborn, T., vom Saal, F.S., and Soto, A.M., 1993, Developmental effects of endocrine-disrupting chemicals in wildlife and humans: Environmental Health Perspectives, v. 101 , p. 378-384.

Crawford, J.K., and Luoma, S.N., 1993, Guidelines for studies of contaminants in biological tissues for the National Water-Quality Assessment Program: U.S. Geological Survey Open-File Report 92-494, 69 p.

Eisler, Ronald, 1987, Mercury hazards to fish, wildlife, and invertebrates - a synoptic review: U.S. Fish and Wildlife Service Biological Report 85 (1.10), 90 p.

Erwin, M.L., and Munn, M.D., 1997, Are wall-eye from Lake Roosevelt contaminated with mercury?: U.S. Geological Survey Fact Sheet 102-97, 4 p.
Foreman, W.T., Connor, B.F., Furlong, E.T., Vaught, D.G., and Merten, L.M., 1995, Methods of analysis by the U.S. Geological Survey National Water Quality Laboratory - determination of organochlorine pesticides and polychlorinated biphenyls in bottom sediment by dual capillary-column gas chromatography with electroncapture detection: U.S. Geological Survey Open-File Report 95-140, $78 \mathrm{p}$.

Gebhards, S., Cline, J., Shields, F., and Pearson, L., 1973, Mercury residues in Idaho fishes, 1970, in Buhler, D.R., ed., Proceedings of the workshop on mercury in the Western environment: Corvallis, Oreg., Oregon State University Continuing Education, p. 76-80.

Goldstein, R.M., Brigham, M.E., and Stauffer, J.C., 1996, Comparison of mercury concentrations in liver, muscle, whole bodies, and composites of fish from the Red River of the North: Canadian Journal of Fishery and Aquatic Science, v. 53, p. 244-252.

Goodbred, S.L., Gilliom, R.J., Gross, T.S., Denslow, N.P., Bryant, W.B., and Schoeb, T.R., 1997, Reconnaissance of $17 \beta$-Estradiol, 11-Ketotestosterone, vitellogenin, and gonad histopathology in Common Carp of United States streams - potential for contamination-induced endocrine disruption: U.S. Geological Survey Open-File Report 96-627, $47 \mathrm{p}$.

Hoffman, G.L., 1996, Methods of analysis by the U.S. Geological Survey National Water Quality Laboratory preparation procedure for aquatic biological material determined for trace metals: U.S. Geological Survey Open-File Report 96-362, 42 p.

Laird, L.B., 1964, Chemical quality of the surface waters of the Snake River Basin: U.S. Geological Survey Professional Paper 417-D, 47 p., 5 pls.

Larson, S.J., Capel, P.D., and Majewski, M.S., 1997, Pesticides in surface waters - distribution, trends, and governing factors: Chelsea, Mich., Ann Arbor Press, Inc., $373 \mathrm{p}$.

Law, R.J., 1996, Metals in marine mammals, in Beyer, W.N., Heinz, G.H., and Redmon-Norwood, A.W., eds., Environmental contaminants in wildlife: Boca Raton, Fla., CRC Press, Inc., p. 357-376.

Leiker, T.J., Madsen, J.E., Deacon, J.R., and Foreman, W.T., 1995, Methods of analysis by the U.S. Geological Survey National Water Quality Laboratory — determination of chlorinated pesticides in aquatic tissue by capillary-column gas chromatography with electroncapture detection: U.S. Geological Survey Open-File Report 94-710, $42 \mathrm{p}$.

Lowe, T.P., May, T.W., Brumbaugh, W.G., and Kane, D.A., 1985, National contaminant biomonitoring program concentrations of seven elements in freshwater fish, 1978-1981: Archives of Environmental Contamination and Toxicology, v. 14, p. 363-388. 
Maret, T.R., 1995a, Mercury in streambed sediment and aquatic biota in the upper Snake River Basin, Idaho and western Wyoming, 1992: U.S. Geological Survey Fact Sheet FS-089-95, 2 p.

-1995b, Water-quality assessment of the upper Snake River Basin, Idaho and western Wyomingsummary of aquatic biological data for surface water through 1992: U.S. Geological Survey WaterResources Investigations R eport 95-4006, 59 p.

Maret, T.R., and Ott, D.S., 1997, Organochlorine compounds in fish tissue and bed sediment in the upper Snake River Basin, Idaho and western Wyoming, 1992-94: U.S. Geological Survey Water-Resources Investigations Report 97-4080, 23 p.

Meador, M.R., Cuffney, T.E., and Gurtz, M.E., 1993, Methods for sampling fish communities as part of the National Water-Quality Assessment Program: U.S. Geological Survey Open-File Report 93-104, 40 p.

National Academy of Sciences and National Academy of Engineering, 1973, Water quality criteria, 1972: Washington, D.C., U.S. Government Printing Office, 594 p.

Nauen, C.E., 1983, Compilation of legal limits for hazardous substances in fish and fishery products: Rome, Food and Agricultural Organization of the United Nations, Circular no. 764, 102 p.

Newell, A.J., Johnson, D.W., and Allen, L.K., 1987, Niagara River biota contamination project - fish flesh criteria for piscivorous wildlife: New York State/Department of Environmental Conservation Technical Report 87-3, $182 \mathrm{p}$.

Nowell, L.H., and Resek, E.A., 1994, Summary of national standards and guidelines for pesticides in water, bed sediment, and aquatic organisms and their application to water-quality assessments: U.S. Geological Survey Open-File Report 94-44, 115 p.

Rainbow, P.S., 1996, Heavy metals in aquatic invertebrates, in Beyer, W.N., Heinz, G.H., and Redmon-Norwood, A.W., eds., Environmental contaminants in wildlife: Boca Raton, Fla., CRC Press, Inc., p. 405-426.
Rasmussen, Del, 1996, Toxic substances monitoring program 1994-95 data report: California State Water Resources Control Board.

Rinella, F.A., Mullins, W.H., and Schuler, C.A., 1994, Reconnaissance investigation of water quality, bottom sediment, and biota associated with irrigation drainage in the Owyhee and Vale projects, Oregon and Idaho, 1990-91: U.S. Geological Survey Water-Resources Investigations Report 93-4156, 101 p.

Schmitt, C.J., and Brumbaugh, W.G., 1990, National Contaminant Biomonitoring Program - residues of organochlorine chemicals in U.S. freshwater fish, 19761984: Archives of Environmental Contamination and Toxicology, v. 19, p. 748-781.

Shelton, L.R., and Capel, P.D., 1994, Guidelines for collecting and processing samples of stream bed sediment for analysis of trace elements and organic contaminants for the National Water-Quality Assessment Program: U.S. Geological Survey Open-File Report 94-458, 20 p.

U.S. Environmental Protection Agency, 1992, National study of chemical residues in fish - Volume 1: Washington, D.C., U.S. Environmental Protection Agency, Office of Science and Technology, 2 vols. (EPA 823-R-92008a, 166 p., 2 apps; EPA-823-R-92-008b, 2 apps. [about 200] p.).

1995, Guidance for assessing chemical contaminant data for use in fish advisories - Volume 1, fish sampling and analysis, 2d ed.: Washington, D.C., U.S. Environmental Protection Agency, Office of Science and Technology, EPA 823-R-95-007, 13 apps. [about 300] p.

-accessed October 1997, National listing of fish consumption advisories, 1996 [online]: Available World Wide Web, http://www.epa.gov/OST/ fishadvice/index.html

Wiener, J.G., and Spry, D.J., 1996, Toxicological significance of mercury in freshwater fish, in Beyer, W.N., Heinz, G.H., and Redmon-Norwood, A.W., eds., Environmental contaminants in wildlife: Boca Raton, Fla., CRC Press, Inc., p. 265-279. 



\section{APPENDICES}

1. Organochlorine compounds in fish-tissue samples from the Snake River Basin, 1992-97 . . . . . . . . 25

2. Organochlorine compounds in bed-sediment samples from the Snake River Basin, 1992-97. . . . . . 28

3. Trace elements in fish-tissue samples from the Snake River Basin, $1992-97 \ldots \ldots \ldots \ldots \ldots \ldots \ldots$

4. Trace elements in bed-sediment samples from the Snake River Basin, $1992-97 \ldots \ldots \ldots \ldots \ldots \ldots$ 

Appendix 1. Organochlorine compounds in fish-tissue samples from the Snake River Basin, 1992-97

[All sites are in Idaho unless otherwise noted; sites are shown in figure 3; WY, Wyoming; OR, Oregon; all concentrations are in units of micrograms per kilogram (wet weight) unless otherwise noted; <, less than; E, estimated value]

\begin{tabular}{|c|c|c|c|c|c|c|c|}
\hline \multirow[b]{2}{*}{$\begin{array}{c}\text { Site } \\
\text { identification }\end{array}$} & \multirow[b]{2}{*}{ Site name } & \multirow{2}{*}{$\begin{array}{c}\text { Date } \\
\text { sampled } \\
(\mathbf{m m} / \mathrm{dd} / \mathrm{yy})\end{array}$} & \multirow[b]{2}{*}{$\begin{array}{l}\text { Fish species } \\
\text { sampled }\end{array}$} & \multirow[b]{2}{*}{$\begin{array}{l}\text { Body part } \\
\text { analyzed }\end{array}$} & \multicolumn{3}{|c|}{ Organochlorine compound } \\
\hline & & & & & Aldrin & $\begin{array}{c}\text { cis- } \\
\text { Chlordane }\end{array}$ & $\begin{array}{c}\text { trans- } \\
\text { Chlordane }\end{array}$ \\
\hline Snk-FR & Snake River at Flagg Ranch, WY & 09/07/95 & Mountain whitefish & Whole body & $<5.0$ & $<5.0$ & $<5.0$ \\
\hline Slt-FC & Salt River near Fish Creek, WY & 08/12/93 & Paiute sculpin & Whole body & $<5.0$ & $<5.0$ & $<5.0$ \\
\hline Slt-ET & Salt River near Etna, WY & 08/16/94 & Utah sucker & Whole body & $<5.0$ & $<5.0$ & $<5.0$ \\
\hline Btc-LA & Bitch Creek near Lamont & 09/14/93 & Mountain whitefish & Whole body & $<5.0$ & $<5.0$ & $<5.0$ \\
\hline Hfk-RX & Henrys Fork near Rexburg & 08/06/96 & Utah sucker & Whole body & $<5.0$ & $<5.0$ & $<5.0$ \\
\hline Bkt-HE & Blackfoot River near Henry & $09 / 22 / 92$ & Common carp & Whole body & $<5.0$ & $<5.0$ & $<5.0$ \\
\hline Snk-BF & Snake River near Blackfoot & 09/10/96 & Utah sucker & Whole body & $<5.0$ & $<5.0$ & $<5.0$ \\
\hline Prt-PC & Portneuf River at Pocatello & $09 / 09 / 96$ & Utah sucker & Whole body & $<5.0$ & $<5.0$ & $<5.0$ \\
\hline Snk-MD & Snake River near Minidoka & $07 / 21 / 93$ & Utah sucker & Whole body & $<5.0$ & $<5.0$ & $<5.0$ \\
\hline Snk-KI & Snake River near Kimberly & 08/25/92 & Utah sucker & Whole body & $<5.0$ & $<5.0$ & $<5.0$ \\
\hline Rck-RK & Rock Creek near Rock Creek & 07/06/93 & Mountain sucker & Whole body & $<5.0$ & $<5.0$ & $<5.0$ \\
\hline Rck-TF & Rock Creek at Twin Falls & 08/17/95 & Bridgelip sucker & Whole body & $<5.0$ & $<5.0$ & $<5.0$ \\
\hline Snk-BU & Snake River near Buhl & 07/23/96 & Largescale sucker & Whole body & $<5.0$ & $<5.0$ & $<5.0$ \\
\hline Bgl-CL & Big Lost River near Chilly & 08/30/94 & Paiute sculpin & Whole body & $<5.0$ & $<5.0$ & $<5.0$ \\
\hline Bgw-KE & Big Wood River near Ketchum & 07/26/93 & Wood River sculpin & Whole body & $<5.0$ & $<5.0$ & $<5.0$ \\
\hline Mld-GD & Malad River near Gooding & $08 / 26 / 93$ & Largescale sucker & Whole body & $<5.0$ & $<5.0$ & $<5.0$ \\
\hline Snk-KH & Snake River at King Hill & $07 / 29 / 97$ & Largescale sucker & Whole body & $<5.0$ & $<5.0$ & $<5.0$ \\
\hline Snk-CJ & C.J. Strike Reservoir at Highway 51 Bridge & 08/04/97 & Largescale sucker & Whole body & $<5.0$ & $<5.0$ & $<5.0$ \\
\hline Snk-CJ & C.J. Strike Reservoir at Highway 51 Bridge & 08/04/97 & Smallmouth bass & Fillet & $<5.0$ & $<5.0$ & $<5.0$ \\
\hline Snk-CJ & C.J. Strike Reservoir at Highway 51 Bridge & 08/04/97 & Yellow perch & Fillet & $<5.0$ & $<5.0$ & $<5.0$ \\
\hline Snk-SF & Swan Falls Reservoir at Swan Falls Dam & 08/05/97 & Largescale sucker & Whole body & $<5.0$ & $<5.0$ & $<5.0$ \\
\hline Boi-TS & Boise River at Twin Springs & 09/04/97 & Largescale sucker & Whole body & $<5.0$ & $<5.0$ & $<5.0$ \\
\hline Boi-PM & Boise River at Parma & $12 / 11 / 96$ & Largescale sucker & Whole body & $<5.0$ & $<10$ & $<10$ \\
\hline Snk-NY & Snake River at Nyssa, OR & 08/06/97 & Largescale sucker & Whole body & $<5.0$ & $<5.0$ & $<5.0$ \\
\hline Snk-NY & Snake River at Nyssa, OR & 08/06/97 & Channel catfish & Fillet & $<5.0$ & E3.5 & $<5.0$ \\
\hline Snk-BR & Brownlee Reservoir at Burnt River, OR & 08/11/97 & Largescale sucker & Whole body & $<5.0$ & 5.2 & $<5.0$ \\
\hline Snk-BR & Brownlee Reservoir at Burnt River, OR & 08/11/97 & Common carp & Whole body & $<5.0$ & 20 & E4.9 \\
\hline Snk-BR & Brownlee Reservoir at Burnt River, OR & 08/11/97 & Smallmouth bass & Fillet & $<5.0$ & $<5.0$ & $<5.0$ \\
\hline Snk-BR & Brownlee Reservoir at Burnt River, OR & 08/11/97 & White crappie & Fillet & $<5.0$ & $<5.0$ & $<5.0$ \\
\hline Snk-BR & Brownlee Reservoir at Burnt River, OR & 08/11/97 & Channel catfish & Fillet & $<5.0$ & 8.0 & $<5.0$ \\
\hline Snk-PL & Snake River at Pittsburg Landing & 08/13/97 & Largescale sucker & Whole body & $<5.0$ & $<5.0$ & $<5.0$ \\
\hline Snk-PL & Snake River at Pittsburg Landing & 08/13/97 & Largescale sucker & Whole body & $<5.0$ & $<5.0$ & $<5.0$ \\
\hline Sal-WB & Salmon River near White Bird & 08/14/97 & Largescale sucker & Whole body & $<5.0$ & $<5.0$ & $<5.0$ \\
\hline
\end{tabular}


Appendix 1. Organochlorine compounds in fish-tissue samples from the Snake River Basin, 1992-97-Continued

\begin{tabular}{|c|c|c|c|c|c|c|c|c|c|c|c|c|c|}
\hline \multirow[b]{2}{*}{$\begin{array}{c}\text { Site } \\
\text { identi- } \\
\text { fication }\end{array}$} & \multicolumn{13}{|c|}{ Organochlorine compound } \\
\hline & DCPA & $\begin{array}{l}o, p^{\prime}- \\
\text { DDD }\end{array}$ & $\begin{array}{l}p, p^{\prime}- \\
\text { DDD }\end{array}$ & $\begin{array}{l}o, p^{\prime}- \\
\text { DDE }\end{array}$ & $\begin{array}{l}p, p^{\prime}- \\
\text { DDE }\end{array}$ & $\begin{array}{l}o, p^{\prime}- \\
\text { DDT }\end{array}$ & $\begin{array}{l}p, p^{\prime}- \\
\text { DDT }\end{array}$ & Dieldrin & Endrin & Heptachlor & $\begin{array}{c}\text { Heptachlor } \\
\text { epoxide }\end{array}$ & $\begin{array}{c}\text { Hexa } \\
\text { chloro- } \\
\text { benzene }\end{array}$ & $\begin{array}{c}\text { alpha- } \\
\mathrm{HCH}\end{array}$ \\
\hline Snk-FR & 5.6 & $<5.0$ & $<5.0$ & $<7.16$ & 16 & $<10$ & $<10$ & $<5.0$ & $<5.0$ & $<5.0$ & $<5.0$ & $<5.0$ & $<5.0$ \\
\hline Slt-FC & $<5.0$ & $<5.0$ & $<5.0$ & $<5.0$ & $<5.0$ & $<5.0$ & $<5.0$ & $<5.0$ & $<5.0$ & $<5.0$ & $<5.0$ & $<5.0$ & $<5.0$ \\
\hline Slt-ET & $<5.0$ & $<5.0$ & $<5.0$ & $<5.0$ & 6.7 & $<5.0$ & $<5.0$ & $<5.0$ & $<5.0$ & $<5.0$ & $<5.0$ & $<5.0$ & $<5.0$ \\
\hline Btc-LA & $<5.0$ & $<5.0$ & $<5.0$ & $<5.0$ & 10 & $<5.0$ & $<5.0$ & $<5.0$ & $<5.0$ & $<5.0$ & $<5.0$ & $<5.0$ & $<5.0$ \\
\hline Hfk-RX & $<5.0$ & $<5.0$ & E16 & $<5.0$ & 290 & $<5.0$ & 17 & $<5.0$ & $<5.0$ & $<5.0$ & $<5.0$ & $<5.0$ & $<5.0$ \\
\hline Bkt-HE & $<5.0$ & $<5.0$ & 22 & $<5.0$ & 31 & $<5.0$ & $<5.0$ & 11.0 & $<5.0$ & $<5.0$ & $<5.0$ & $<5.0$ & $<5.0$ \\
\hline Snk-BF & $<5.0$ & $<5.0$ & E17 & $<5.0$ & 250 & $<5.0$ & 13 & $<5.0$ & $<5.0$ & $<5.0$ & $<5.0$ & $<5.0$ & $<5.0$ \\
\hline Prt-PC & $<5.0$ & $<5.0$ & $<5.0$ & $<5.0$ & 47 & $<5.0$ & E13 & $<5.0$ & $<5.0$ & $<5.0$ & $<5.0$ & $<5.0$ & $<5.0$ \\
\hline Snk-MD & $<5.0$ & $<5.0$ & 8.5 & $<5.0$ & 47 & $<5.0$ & $<5.0$ & $<5.0$ & $<5.0$ & $<5.0$ & $<5.0$ & $<5.0$ & $<5.0$ \\
\hline Snk-KI & $<5.0$ & $<5.0$ & 18 & $<5.0$ & 520 & $<5.0$ & 52 & $<5.0$ & $<5.0$ & $<5.0$ & $<5.0$ & $<5.0$ & $<5.0$ \\
\hline Rck-RK & $<5.0$ & $<5.0$ & $<5.0$ & $<5.0$ & $<5.0$ & $<5.0$ & $<5.0$ & $<5.0$ & $<5.0$ & $<5.0$ & $<5.0$ & $<5.0$ & $<5.0$ \\
\hline Rck-TF & 16 & $<5.0$ & E21 & $<8.1$ & 490 & $<5.0$ & 50 & 6.2 & $<5.0$ & $<5.0$ & $<5.0$ & $<5.0$ & $<5.0$ \\
\hline Snk-BU & $<5.0$ & $<5.0$ & E17 & $<5.0$ & 470 & $<5.0$ & E11 & $<5.0$ & $<5.0$ & $<5.0$ & $<5.0$ & $<5.0$ & $<5.0$ \\
\hline Bgl-CL & $<5.0$ & $<5.0$ & $<5.0$ & $<5.0$ & 7.9 & $<5.0$ & $<5.0$ & $<5.0$ & $<5.0$ & $<5.0$ & $<5.0$ & $<5.0$ & $<5.0$ \\
\hline Bgw-KE & $<5.0$ & $<5.0$ & $<5.0$ & $<5.0$ & $<5.0$ & $<5.0$ & $<5.0$ & $<5.0$ & $<5.0$ & $<5.0$ & $<5.0$ & $<5.0$ & $<5.0$ \\
\hline Mld-GD & $<5.0$ & $<5.0$ & 9.0 & $<5.0$ & 120 & $<5.0$ & $<5.0$ & $<5.0$ & $<5.0$ & $<5.0$ & $<5.0$ & $<5.0$ & $<5.0$ \\
\hline Snk-KH & $<5.0$ & $<5.0$ & $<5.0$ & $<5.0$ & 160 & $<5.0$ & $<5.0$ & $<5.0$ & $<5.0$ & $<5.0$ & $<5.0$ & $<5.0$ & $<5.0$ \\
\hline Snk-CJ & $<5.0$ & $<5.0$ & 12 & $<5.0$ & 200 & $<5.0$ & $<5.0$ & $<5.0$ & $<5.0$ & $<5.0$ & $<5.0$ & $<5.0$ & $<5.0$ \\
\hline Snk-CJ & $<5.0$ & $<5.0$ & $<5.0$ & $<5.0$ & 20 & $<5.0$ & $<5.0$ & $<5.0$ & $<5.0$ & $<5.0$ & $<5.0$ & $<5.0$ & $<5.0$ \\
\hline Snk-CJ & $<5.0$ & $<5.0$ & $<5.0$ & $<5.0$ & 11 & $<5.0$ & $<5.0$ & $<5.0$ & $<5.0$ & $<5.0$ & $<5.0$ & $<5.0$ & $<5.0$ \\
\hline Snk-SF & $<5.0$ & $<5.0$ & 13 & $<7.0$ & 210 & $<5.0$ & 7.2 & $<5.0$ & $<5.0$ & $<5.0$ & $<5.0$ & $<5.0$ & $<6.0$ \\
\hline Boi-TS & $<5.0$ & $<5.0$ & 5.1 & $<5.0$ & 79 & $<5.0$ & 14 & $<5.0$ & $<5.0$ & $<5.0$ & $<5.0$ & $<5.0$ & $<5.0$ \\
\hline Boi-PM & $<5.0$ & 5.5 & 52 & $<10$ & 770 & $<10$ & E60 & 14 & $<16$ & $<5.0$ & $<10$ & $<5.0$ & $<6.7$ \\
\hline Snk-NY & $<5.0$ & $<5.0$ & 24 & E9.3 & 510 & $<12$ & 50 & $<5.0$ & $<5.0$ & $<5.0$ & $<5.0$ & $<5.0$ & $<5.0$ \\
\hline Snk-NY & $<5.0$ & $<5.0$ & 45 & $<5.0$ & 690 & $<5.0$ & 41 & 12 & $<5.0$ & $<5.0$ & $<5.0$ & $<5.0$ & $<5.0$ \\
\hline Snk-BR & $<5.0$ & E13 & 120 & $<5.0$ & 1,300 & $<5.0$ & 72 & 19 & $<5.0$ & $<5.0$ & $<5.0$ & 6.3 & $<5.0$ \\
\hline Snk-BR & $<16$ & 24 & 281 & $<30$ & 3,300 & 13 & 15 & 37 & $<5.0$ & $<5.0$ & $<5.0$ & 11 & $<5.0$ \\
\hline Snk-BR & $<5.0$ & $<5.0$ & 6.3 & $<5.0$ & 99 & $<5.0$ & 7.2 & $<5.0$ & $<5.0$ & $<5.0$ & $<5.0$ & $<5.0$ & $<5.0$ \\
\hline Snk-BR & $<5.0$ & $<5.0$ & 5.2 & $<5.0$ & 84 & $<5.0$ & 6.9 & $<5.0$ & $<5.0$ & $<5.0$ & $<5.0$ & $<5.0$ & $<5.0$ \\
\hline Snk-BR & $<5.5$ & 6.9 & 76 & E10 & 960 & E7.0 & 39 & 20 & $<5.0$ & $<5.0$ & $<5.0$ & E4.2 & $<5.0$ \\
\hline Snk-PL & $<5.0$ & $<24$ & 14 & $<5.0$ & 170 & $<5.0$ & 7.1 & $<5.0$ & $<5.0$ & $<5.0$ & $<5.0$ & $<5.0$ & $<5.0$ \\
\hline Snk-PL & $<5.0$ & $<5.0$ & 5.2 & $<5.0$ & 90 & $<5.0$ & E3.7 & E3.8 & $<5.0$ & $<5.0$ & $<5.0$ & $<5.0$ & $<5.0$ \\
\hline Sal-WB & $<5.0$ & $<5.0$ & $<5.0$ & $<5.0$ & 33 & $<5.0$ & 5.9 & $<5.0$ & $<5.0$ & $<5.0$ & $<5.0$ & $<5.0$ & $<5.0$ \\
\hline
\end{tabular}


Appendix 1. Organochlorine compounds in fish-tissue samples from the Snake River Basin, 1992-97-Continued

\begin{tabular}{|c|c|c|c|c|c|c|c|c|c|c|c|c|c|}
\hline \multirow[b]{2}{*}{$\begin{array}{c}\text { Site } \\
\text { identi- } \\
\text { fication }\end{array}$} & \multicolumn{12}{|c|}{ Organochlorine compound } & \multirow[b]{2}{*}{$\begin{array}{c}\text { Lipids } \\
\text { (percent) }\end{array}$} \\
\hline & $\begin{array}{l}\text { beta- } \\
\text { HCH }\end{array}$ & $\begin{array}{l}\text { delta- } \\
\mathrm{HCH}\end{array}$ & $\begin{array}{c}\text { gamma- } \\
\text { HCH } \\
\text { (Lindane) }\end{array}$ & $\begin{array}{c}\text { o,p'- } \\
\text { Meth- } \\
\text { oxychlor }\end{array}$ & $\begin{array}{c}p, p '- \\
\text { Meth- } \\
\text { oxychlor }\end{array}$ & Mirex & $\begin{array}{c}\text { cis- } \\
\text { Nonachlor }\end{array}$ & $\begin{array}{c}\text { trans- } \\
\text { Nonachlor }\end{array}$ & $\begin{array}{c}\text { Oxy- } \\
\text { chlordane }\end{array}$ & $\begin{array}{l}\text { Penta- } \\
\text { chloro- } \\
\text { anisole }\end{array}$ & $\begin{array}{l}\text { Toxa- } \\
\text { phene }\end{array}$ & $\begin{array}{l}\text { Total } \\
\text { PCBs }\end{array}$ & \\
\hline Snk-FR & $<5.2$ & $<5.6$ & $<5.0$ & $<10$ & $<10$ & $<5.0$ & $<5.0$ & $<5.0$ & $<5.3$ & $<5.0$ & $<200$ & $<50$ & 5.2 \\
\hline Slt-FC & $<5.0$ & $<5.0$ & $<5.0$ & $<5.0$ & $<5.0$ & $<5.0$ & $<5.0$ & $<5.0$ & $<5.0$ & $<5.0$ & $<200$ & $<50$ & 2.9 \\
\hline Slt-ET & $<5.0$ & $<5.0$ & $<5.0$ & $<5.0$ & $<5.0$ & $<5.0$ & $<5.0$ & $<5.0$ & $<5.0$ & $<5.0$ & $<200$ & $<50$ & 6.6 \\
\hline Btc-LA & $<5.0$ & $<5.0$ & $<5.0$ & $<5.0$ & $<5.0$ & $<5.0$ & $<5.0$ & $<5.0$ & $<5.0$ & $<5.0$ & $<200$ & $<50$ & 7.9 \\
\hline Hfk-RX & $<5.0$ & $<5.0$ & $<5.0$ & $<5.0$ & $<5.0$ & $<5.0$ & $<5.0$ & $<5.0$ & $<5.0$ & $<5.0$ & $<200$ & $<51$ & 13 \\
\hline Bkt-HE & $<5.0$ & $<14$ & $<5.0$ & $<5.0$ & $<5.0$ & $<5.0$ & $<5.0$ & $<5.0$ & $<5.0$ & $<5.0$ & $<200$ & $<50$ & 14 \\
\hline Snk-BF & $<5.0$ & $<5.0$ & $<5.0$ & $<5.0$ & $<5.0$ & $<5.0$ & $<5.0$ & $<5.0$ & $<5.0$ & $<5.0$ & $<200$ & 60 & 16 \\
\hline Prt-PC & $<5.0$ & $<5.0$ & $<5.0$ & $<5.0$ & $<5.0$ & $<5.0$ & $<5.0$ & 6.4 & $<5.0$ & $<5.0$ & $<200$ & 240 & 4.2 \\
\hline Snk-MD & $<5.0$ & $<5.0$ & $<5.0$ & $<5.0$ & $<5.0$ & $<5.0$ & $<5.0$ & $<5.0$ & $<5.0$ & $<5.0$ & $<200$ & $<50$ & 11 \\
\hline Snk-KI & $<5.0$ & $<5.0$ & $<5.0$ & $<5.0$ & $<5.0$ & $<5.0$ & $<5.0$ & 7.7 & $<5.0$ & $<5.0$ & $<200$ & 50 & 6.6 \\
\hline Rck-RK & $<5.0$ & $<5.0$ & $<5.0$ & $<5.0$ & $<5.0$ & $<5.0$ & $<5.0$ & $<5.0$ & $<5.0$ & $<5.0$ & $<200$ & $<50$ & 6.0 \\
\hline Rck-TF & $<5.0$ & $<5.0$ & $<5.0$ & $<5.0$ & $<5.0$ & $<5.0$ & $<5.0$ & $<5.0$ & $<5.0$ & $<5.0$ & 260 & $<50$ & 5.5 \\
\hline Snk-BU & $<5.0$ & $<5.0$ & $<5.0$ & $<5.0$ & $<5.0$ & $<5.0$ & $<5.0$ & 5.3 & $<5.0$ & $<5.0$ & $<200$ & $<50$ & 6.4 \\
\hline Bgl-CL & $<5.0$ & $<5.0$ & $<5.0$ & $<5.0$ & $<5.0$ & $<5.0$ & $<5.0$ & $<5.0$ & $<5.0$ & $<5.0$ & $<200$ & $<50$ & 3.3 \\
\hline $\mathrm{Bgw}-\mathrm{KE}$ & $<5.0$ & $<5.0$ & $<5.0$ & $<5.0$ & $<5.0$ & $<5.0$ & $<5.0$ & $<5.0$ & $<5.0$ & $<5.0$ & $<200$ & $<50$ & 5.7 \\
\hline Mld-GD & $<5.0$ & $<5.0$ & $<5.0$ & $<5.0$ & $<5.0$ & $<5.0$ & $<5.0$ & 5.5 & $<5.0$ & $<5.0$ & $<200$ & 54 & 9.8 \\
\hline Snk-KH & $<5.0$ & $<5.0$ & $<5.0$ & $<5.0$ & $<5.0$ & $<5.0$ & $<5.0$ & $<5.0$ & $<5.0$ & $<5.0$ & $<200$ & $<50$ & 3.2 \\
\hline Snk-CJ & $<5.0$ & $<5.0$ & $<5.0$ & $<5.0$ & $<5.0$ & $<5.0$ & $<5.0$ & $<5.0$ & $<5.0$ & $<5.0$ & $<200$ & 56 & 6.0 \\
\hline Snk-CJ & $<5.0$ & $<5.0$ & $<5.0$ & $<5.0$ & $<5.0$ & $<5.0$ & $<5.0$ & $<5.0$ & $<5.0$ & $<5.0$ & $<200$ & $<50$ & 5.5 \\
\hline Snk-CJ & $<5.0$ & $<5.0$ & $<5.0$ & $<5.0$ & $<5.0$ & $<5.0$ & $<5.0$ & $<5.0$ & $<5.0$ & $<5.0$ & $<200$ & $<50$ & 1.7 \\
\hline Snk-SF & $<5.0$ & $<5.0$ & $<5.0$ & $<5.0$ & $<5.0$ & $<5.0$ & $<5.0$ & E4.7 & $<5.0$ & $<5.0$ & $<200$ & $<50$ & 13 \\
\hline Boi-TS & $<5.0$ & $<5.0$ & $<5.0$ & $<5.0$ & $<5.0$ & $<5.0$ & $<5.0$ & $<5.0$ & $<5.0$ & $<5.0$ & $<200$ & $<50$ & 3.0 \\
\hline Boi-PM & $<5.0$ & $<7.9$ & $<5.4$ & $<10$ & $<10$ & $<5.0$ & $<10$ & E13 & $<5.0$ & $<5.0$ & $<200$ & 99 & 21.5 \\
\hline Snk-NY & $<5.0$ & $<5.0$ & $<5.0$ & $<5.0$ & $<5.0$ & $<5.0$ & $<5.0$ & $<5.0$ & $<5.0$ & $<5.0$ & $<200$ & $<50$ & 10 \\
\hline Snk-NY & $<5.0$ & $<5.0$ & $<5.0$ & $<5.0$ & $<5.0$ & $<5.0$ & $<5.0$ & 7.0 & $<5.0$ & $<5.0$ & $<200$ & $<50$ & 6.6 \\
\hline Snk-BR & $<5.0$ & $<5.0$ & $<5.0$ & $<5.0$ & $<5.0$ & $<5.0$ & $<5.0$ & 7.8 & $<5.0$ & $<5.0$ & $<200$ & 61 & 12 \\
\hline Snk-BR & $<5.0$ & $<16$ & $<5.0$ & $<16$ & $<5.0$ & $<5.0$ & 9.3 & 25 & $<5.0$ & $<5.0$ & $<200$ & 160 & 35 \\
\hline Snk-BR & $<5.0$ & $<5.0$ & $<5.0$ & $<5.0$ & $<5.0$ & $<5.0$ & $<5.0$ & $<5.0$ & $<5.0$ & $<5.0$ & $<200$ & $<50$ & 1.4 \\
\hline Snk-BR & $<5.0$ & $<5.0$ & $<5.0$ & $<5.0$ & $<5.0$ & $<5.0$ & $<5.0$ & $<5.0$ & $<5.0$ & $<5.0$ & $<200$ & $<50$ & 1.8 \\
\hline Snk-BR & $<5.0$ & $<6.0$ & $<5.0$ & $<5.0$ & $<5.0$ & $<5.0$ & E4.1 & 10 & $<5.0$ & $<5.0$ & $<200$ & $<50$ & 12 \\
\hline Snk-PL & $<5.0$ & $<5.0$ & $<5.0$ & $<5.0$ & $<5.0$ & $<5.0$ & $<5.0$ & $<5.0$ & $<5.0$ & $<5.0$ & $<200$ & $<50$ & 3.2 \\
\hline Snk-PL & $<5.0$ & $<5.0$ & $<5.0$ & $<5.0$ & $<5.0$ & $<5.0$ & $<5.0$ & $<5.0$ & $<5.0$ & $<5.0$ & $<200$ & $<50$ & 4.1 \\
\hline Sal-WB & $<5.0$ & $<5.0$ & $<5.0$ & $<5.0$ & $<5.0$ & $<5.0$ & $<5.0$ & $<5.0$ & $<5.0$ & $<5.0$ & $<200$ & $<50$ & 5.5 \\
\hline
\end{tabular}


Appendix 2. Organochlorine compounds in bed-sediment samples from the Snake River Basin, 1992-97

[All sites are in Idaho unless otherwise noted; sites are shown in figure 3; WY, Wyoming; OR, Oregon; all concentrations are in units of micrograms per kilogram (dry weight) unless otherwise noted; $\mu \mathrm{m}$, micrometer; <, less than; E, estimated value; —, no data available; $\mathrm{g} / \mathrm{kg}$, grams per kilogram]

\begin{tabular}{|c|c|c|c|c|c|c|c|c|c|c|c|c|c|}
\hline \multirow[b]{2}{*}{$\begin{array}{c}\text { Site } \\
\text { identification }\end{array}$} & \multirow[b]{2}{*}{ Site name } & \multirow[b]{2}{*}{$\begin{array}{l}\text { Date sampled } \\
(\mathrm{mm} / \mathrm{dd} / \mathrm{yy})\end{array}$} & \multicolumn{11}{|c|}{ Organochlorine compound } \\
\hline & & & Aldrin & $\begin{array}{l}\text { cis- } \\
\text { Chlordane }\end{array}$ & $\begin{array}{c}\text { trans- } \\
\text { Chlordane }\end{array}$ & Chloroneb & Dacthal & $\begin{array}{l}o, p^{\prime}- \\
\text { DDD }\end{array}$ & $\begin{array}{l}p, p^{\prime}- \\
\text { DDD }\end{array}$ & $\begin{array}{l}o, p^{\prime}- \\
\text { DDE }\end{array}$ & $\begin{array}{l}p, p^{\prime}- \\
\text { DDE }\end{array}$ & $\begin{array}{l}o, p^{\prime}- \\
\text { DDT }\end{array}$ & $\begin{array}{l}p, p^{\prime}- \\
\text { DDT }\end{array}$ \\
\hline Snk-FR & Snake River at Flagg Ranch, WY & 09/06/95 & $<1.0$ & $<1.0$ & $<1.0$ & $<5.0$ & $<5.0$ & $<1.0$ & $<1.0$ & $<1.0$ & $<1.0$ & $<2.0$ & $<2.0$ \\
\hline Slt-FC & Salt River near Fish Creek, WY & $08 / 12 / 93$ & $<1.0$ & $<1.0$ & $<1.0$ & $<5.0$ & $<5.0$ & $<1.0$ & $<1.0$ & $<1.0$ & $<1.0$ & $<2.0$ & $<2.0$ \\
\hline Slt-ET & Salt River near Etna, WY & 08/16/94 & $<1.0$ & $<1.0$ & $<1.0$ & $<5.0$ & $<5.0$ & $<1.0$ & $<1.0$ & $<1.0$ & $<1.0$ & $<2.0$ & $<2.0$ \\
\hline Btc-LA & Bitch Creek near Lamont & $09 / 14 / 93$ & $<1.0$ & $<1.0$ & $<1.0$ & $<5.0$ & $<5.0$ & $<1.0$ & $<1.0$ & $<1.0$ & $<1.0$ & $<2.0$ & $<2.0$ \\
\hline Hfk-RX & Henrys Fork near Rexburg & $08 / 16 / 93$ & $<1.0$ & $<1.0$ & $<1.0$ & $<5.0$ & $<5.0$ & $<1.0$ & $<1.0$ & $<1.0$ & 2.1 & $<2.0$ & $<2.0$ \\
\hline Bkt-HE & Blackfoot River near Henry & $09 / 22 / 92$ & $<1.0$ & $<1.0$ & $<1.0$ & $<5.0$ & $<5.0$ & $<1.0$ & $<1.0$ & $<1.0$ & $<1.0$ & $<2.0$ & $<2.0$ \\
\hline Snk-BF & Snake River near Blackfoot & $09 / 07 / 93$ & $<1.0$ & $<1.0$ & $<1.0$ & $<5.0$ & $<5.0$ & $<1.0$ & $<1.0$ & $<1.0$ & $<1.0$ & $<2.0$ & $<2.0$ \\
\hline Prt-PC & Portneuf River at Pocatello & 09/17/92 & $<1.0$ & 1.4 & 2.0 & $<5.0$ & $<5.0$ & 1.0 & 3.7 & $<1.0$ & 2.0 & $<2.0$ & $<2.0$ \\
\hline Snk-MD & Snake River near Minidoka & $07 / 22 / 93$ & $<1.0$ & $<1.0$ & $<1.0$ & $<5.0$ & $<5.0$ & $<1.0$ & $<1.0$ & $<1.0$ & 1.4 & $<2.0$ & $<2.0$ \\
\hline Snk-KI & Snake River near Kimberly & $08 / 27 / 92$ & $<1.0$ & $<1.0$ & $<1.0$ & $<5.0$ & $<5.0$ & $<1.0$ & $<1.0$ & $<1.0$ & $<1.0$ & $<2.0$ & $<2.0$ \\
\hline Rck-RK & Rock Creek near Rock Creek & $07 / 06 / 93$ & $<1.0$ & $<1.0$ & $<1.0$ & $<5.0$ & $<5.0$ & $<1.0$ & $<1.0$ & $<1.0$ & $<1.0$ & $<2.0$ & $<2.0$ \\
\hline Rck-TF & Rock Creek at Twin Falls & $07 / 21 / 97$ & $<1.0$ & $<1.0$ & $<1.0$ & $<5.0$ & $<5.0$ & $<1.0$ & 1.2 & $<1.0$ & 10 & $<2.0$ & 4.0 \\
\hline Snk-BU & Snake River near Buhl & $07 / 20 / 93$ & $<1.0$ & $<1.0$ & $<1.0$ & $<5.0$ & $<5.0$ & $<1.0$ & $<1.0$ & $<1.0$ & 4.5 & $<2.0$ & $<2.0$ \\
\hline Bgl-CL & Big Lost River near Chilly & $08 / 29 / 94$ & $<1.0$ & $<1.0$ & $<1.0$ & $<5.0$ & $<5.0$ & $<1.0$ & $<1.0$ & $<1.0$ & $<1.0$ & $<2.0$ & $<2.0$ \\
\hline Bgw-KE & Big Wood River near Ketchum & $07 / 26 / 93$ & $<1.0$ & $<1.0$ & $<1.0$ & $<5.0$ & $<5.0$ & $<1.0$ & $<1.0$ & $<1.0$ & $<1.0$ & $<2.0$ & $<2.0$ \\
\hline Mld-GD & Malad River near Gooding & $08 / 26 / 93$ & $<1.0$ & $<1.0$ & $<1.0$ & $<5.0$ & $<5.0$ & $<1.0$ & $<1.0$ & $<1.0$ & $<1.0$ & $<2.0$ & $<2.0$ \\
\hline Snk-KH & Snake River at King Hill & $07 / 28 / 97$ & $<1.0$ & $<1.0$ & $<1.0$ & $<5.0$ & $<5.0$ & $<1.0$ & $<1.0$ & $<1.0$ & E.4 & $<2.0$ & $<2.0$ \\
\hline Snk-CJ & C.J. Strike Reservoir at Highway 51 Bridge & 08/04/97 & $<1.0$ & $<1.0$ & $<1.0$ & $<5.0$ & $<5.0$ & $<1.0$ & $<1.0$ & $<1.0$ & 1.1 & $<2.0$ & $<2.0$ \\
\hline Snk-BR & Brownlee Reservoir at Burnt River, OR & $08 / 12 / 97$ & $<1.0$ & $<1.0$ & $<1.0$ & $<5.0$ & E.5 & $<1.0$ & 4.6 & $<1.0$ & 11 & $<2.0$ & 8.1 \\
\hline Snk-MM & Brownlee Reservoir at Mountain Man & $08 / 12 / 97$ & $<1.0$ & $<1.0$ & $<1.0$ & $<5.0$ & $<5.0$ & $<1.0$ & 1.8 & $<1.0$ & 5.7 & $<2.0$ & $<2.0$ \\
\hline
\end{tabular}


Appendix 2. Organochlorine compounds in bed-sediment samples from the Snake River Basin, 1992-97-Continued

\begin{tabular}{|c|c|c|c|c|c|c|c|c|c|c|c|c|c|}
\hline \multirow[b]{2}{*}{$\begin{array}{c}\text { Site } \\
\text { identification }\end{array}$} & \multicolumn{13}{|c|}{ Organochlorine compound } \\
\hline & Dieldrin & Endosulfan & Endrin & Heptachlor & $\begin{array}{l}\text { Heptachlor } \\
\text { epoxide }\end{array}$ & $\begin{array}{l}\text { Hexachloro- } \\
\text { benzene }\end{array}$ & $\begin{array}{l}\text { alpha- } \\
\mathrm{HCH}\end{array}$ & $\begin{array}{l}\text { beta- } \\
\text { HCH }\end{array}$ & $\begin{array}{l}\text { delta- } \\
\mathrm{HCH}\end{array}$ & $\begin{array}{c}\text { gamma- } \\
\text { HCH } \\
\text { (Lindane) }\end{array}$ & Isodrin & $\begin{array}{c}o, p- \\
\text { Methoxychlor }\end{array}$ & $\begin{array}{c}p, p=- \\
\text { Methoxychlor }\end{array}$ \\
\hline Snk-FR & $<1.0$ & $<1.0$ & $<2.0$ & $<1.0$ & $<1.0$ & $<1.0$ & $<1.0$ & $<1.0$ & $<1.0$ & $<1.0$ & $<1.0$ & $<5.0$ & $<5.0$ \\
\hline Slt-FC & $<1.0$ & $<1.0$ & $<2.0$ & $<1.0$ & $<1.0$ & $<1.0$ & $<1.0$ & $<1.0$ & $<1.0$ & $<1.0$ & $<1.0$ & $<5.0$ & $<5.0$ \\
\hline Slt-ET & $<1.0$ & $<1.0$ & $<2.0$ & $<1.0$ & $<1.0$ & $<1.0$ & $<1.0$ & $<1.0$ & $<1.0$ & $<1.0$ & $<1.0$ & $<5.0$ & $<5.0$ \\
\hline Btc-LA & $<1.0$ & $<1.0$ & $<2.0$ & $<1.0$ & $<1.0$ & $<1.0$ & $<1.0$ & $<1.0$ & $<1.0$ & $<1.0$ & $<1.0$ & $<5.0$ & $<5.0$ \\
\hline Hfk-RX & $<1.0$ & $<1.0$ & $<2.0$ & $<1.0$ & $<1.0$ & $<1.0$ & $<1.0$ & $<1.0$ & $<1.0$ & $<1.0$ & $<1.0$ & $<5.0$ & $<5.0$ \\
\hline Bkt-HE & $<1.0$ & $<1.0$ & $<2.0$ & $<1.0$ & $<1.0$ & $<1.0$ & $<1.0$ & $<1.0$ & $<1.0$ & $<1.0$ & $<1.0$ & $<5.0$ & $<5.0$ \\
\hline Snk-BF & $<1.0$ & $<1.0$ & $<2.0$ & $<1.0$ & $<1.0$ & $<1.0$ & $<1.0$ & $<1.0$ & $<1.0$ & $<1.0$ & $<1.0$ & $<5.0$ & $<5.0$ \\
\hline Prt-PC & $<1.0$ & $<1.0$ & $<2.0$ & $<1.0$ & $<1.0$ & $<1.0$ & $<1.0$ & $<1.0$ & $<1.0$ & $<1.0$ & $<1.0$ & $<6.0$ & $<7.0$ \\
\hline Snk-MD & $<1.0$ & $<1.0$ & $<2.0$ & $<1.0$ & $<1.0$ & $<1.0$ & $<1.0$ & $<1.0$ & $<1.0$ & $<1.0$ & $<1.0$ & $<5.0$ & $<5.0$ \\
\hline Snk-KI & $<1.0$ & $<1.0$ & $<2.0$ & $<1.0$ & $<1.0$ & $<1.0$ & $<1.0$ & $<1.0$ & $<1.0$ & $<1.0$ & $<1.0$ & $<5.0$ & $<5.0$ \\
\hline Rck-RK & $<1.0$ & $<1.0$ & $<2.0$ & $<1.0$ & $<1.0$ & $<1.0$ & $<1.0$ & $<1.0$ & $<1.0$ & $<1.0$ & $<1.0$ & $<5.0$ & $<5.0$ \\
\hline Rck-TF & $<1.0$ & $<1.0$ & $<2.0$ & $<1.0$ & $<1.0$ & $<1.0$ & $<1.0$ & $<1.0$ & $<1.0$ & $<1.0$ & $<1.0$ & $<5.0$ & $<5.0$ \\
\hline Snk-BU & $<1.0$ & $<1.0$ & $<2.0$ & $<1.0$ & $<1.0$ & $<1.0$ & $<1.0$ & $<1.0$ & $<1.0$ & $<1.0$ & $<1.0$ & $<5.0$ & $<5.0$ \\
\hline Bgl-CL & $<1.0$ & $<1.0$ & $<2.0$ & $<1.0$ & $<1.0$ & $<1.0$ & $<1.0$ & $<1.0$ & $<1.0$ & $<1.0$ & $<1.0$ & $<5.0$ & $<5.0$ \\
\hline Bgw-KE & $<1.0$ & $<1.0$ & $<2.0$ & $<1.0$ & $<1.0$ & $<1.0$ & $<1.0$ & $<1.0$ & $<1.0$ & $<1.0$ & $<1.0$ & $<5.0$ & $<5.0$ \\
\hline Mld-GD & $<1.0$ & $<1.0$ & $<2.0$ & $<1.0$ & $<1.0$ & $<1.0$ & $<1.0$ & $<1.0$ & $<1.0$ & $<1.0$ & $<1.0$ & $<5.0$ & $<5.0$ \\
\hline Snk-KH & $<1.0$ & $<1.0$ & $<2.0$ & $<1.0$ & $<1.0$ & $<1.0$ & $<1.0$ & $<1.0$ & $<1.0$ & $<1.0$ & $<1.0$ & $<5.0$ & $<5.0$ \\
\hline Snk-CJ & $<1.0$ & $<1.0$ & $<2.0$ & $<1.0$ & $<1.0$ & $<1.0$ & $<1.0$ & $<1.0$ & $<1.0$ & $<1.0$ & $<1.0$ & $<5.0$ & $<5.0$ \\
\hline Snk-BR & E.7 & $<1.0$ & $<2.0$ & $<1.0$ & $<1.0$ & 1.1 & $<1.0$ & $<1.0$ & $<1.0$ & $<1.0$ & $<1.0$ & $<5.0$ & $<5.0$ \\
\hline Snk-MM & $<1.0$ & $<1.0$ & $<2.0$ & $<1.0$ & $<1.0$ & $<1.0$ & $<1.0$ & $<1.0$ & $<1.0$ & $<1.0$ & $<1.0$ & $<5.0$ & $<5.0$ \\
\hline
\end{tabular}


Appendix 2. Organochlorine compounds in bed-sediment samples from the Snake River Basin, 1992-97-Continued

\begin{tabular}{|c|c|c|c|c|c|c|c|c|c|c|c|c|}
\hline \multirow[b]{2}{*}{$\begin{array}{c}\text { Site } \\
\text { identification }\end{array}$} & \multicolumn{9}{|c|}{ Organochlorine compound } & \multirow[b]{2}{*}{$\begin{array}{c}\text { Inorganic } \\
\text { carbon } \\
(\mathbf{g} / \mathbf{k g})\end{array}$} & \multirow[b]{2}{*}{$\begin{array}{c}\text { Organic } \\
\text { carbon } \\
(\mathbf{g} / \mathbf{k g})\end{array}$} & \multirow[b]{2}{*}{$\begin{array}{l}\text { Particle size } \\
\text { (percent less } \\
\text { than } 0.62 \mu \mathrm{m} \text { ) }\end{array}$} \\
\hline & Mirex & $\begin{array}{c}\text { cis- } \\
\text { Nonachlor }\end{array}$ & $\begin{array}{c}\text { trans- } \\
\text { Nonachlor }\end{array}$ & Oxychlordane & $\begin{array}{c}\text { Penta- } \\
\text { chloroanisole }\end{array}$ & $\begin{array}{c}\text { cis- } \\
\text { Permethrin }\end{array}$ & $\begin{array}{c}\text { trans- } \\
\text { Permethrin }\end{array}$ & $\begin{array}{l}\text { Total } \\
\text { PCBs }\end{array}$ & Toxaphene & & & \\
\hline Snk-FR & $<1.0$ & $<1.0$ & $<1.0$ & $<1.0$ & $<1.0$ & $<5.0$ & $<5.0$ & $<50$ & $<200$ & 0.6 & 13 & 14 \\
\hline Slt-FC & $<1.0$ & $<1.0$ & $<1.0$ & $<1.0$ & $<1.0$ & $<5.0$ & - & $<50$ & $<200$ & 4.9 & 18 & 43 \\
\hline Slt-ET & $<1.0$ & $<1.0$ & $<1.0$ & $<1.0$ & $<1.0$ & $<5.0$ & $<5.0$ & $<50$ & $<200$ & 24 & 18 & 51 \\
\hline Btc-LA & $<1.0$ & $<1.0$ & $<1.0$ & $<1.0$ & $<1.0$ & $<5.0$ & - & $<50$ & $<200$ & 7.5 & 26 & 41 \\
\hline Hfk-RX & $<1.0$ & $<1.0$ & $<1.0$ & $<1.0$ & $<1.0$ & $<5.0$ & $<5.0$ & $<50$ & $<200$ & 2.7 & 13 & 31 \\
\hline Bkt-HE & $<1.0$ & $<1.0$ & $<1.0$ & $<1.0$ & $<1.0$ & $<5.0$ & $<5.0$ & $<100$ & $<200$ & 8.7 & 19 & 28 \\
\hline Snk-BF & $<1.0$ & $<1.0$ & $<1.0$ & $<1.0$ & $<1.0$ & $<5.0$ & - & $<50$ & $<200$ & 13 & 8.0 & 21 \\
\hline Prt-PC & $<1.0$ & 1.2 & 1.4 & $<1.0$ & $<1.0$ & $<5.0$ & $<5.0$ & $<100$ & $<200$ & 27 & 28 & 55 \\
\hline Snk-MD & $<1.0$ & $<1.0$ & $<1.0$ & $<1.0$ & $<1.0$ & $<5.0$ & $<5.0$ & $<50$ & $<200$ & 24 & 54 & 60 \\
\hline Snk-KL & $<1.0$ & $<1.0$ & $<1.0$ & $<1.0$ & $<1.0$ & $<5.0$ & $<5.0$ & $<50$ & $<200$ & 7.2 & 2.8 & 4 \\
\hline Rck-RC & $<1.0$ & $<1.0$ & $<1.0$ & $<1.0$ & $<1.0$ & $<5.0$ & - & $<50$ & $<200$ & .4 & 35 & 43 \\
\hline Rck-TF & $<1.0$ & $<1.0$ & $<1.0$ & $<1.0$ & $<1.0$ & $<5.0$ & $<5.0$ & $<50$ & $<200$ & 5.5 & 10 & 36 \\
\hline Snk-BU & $<1.0$ & $<1.0$ & $<1.0$ & $<1.0$ & $<1.0$ & $<5.0$ & - & $<50$ & $<200$ & 12 & 10 & 44 \\
\hline Bgl-CL & $<1.0$ & $<1.0$ & $<1.0$ & $<1.0$ & $<1.0$ & $<5.0$ & $<5.0$ & $<50$ & $<200$ & $<.1$ & 24 & 20 \\
\hline Bgw-KE & $<1.0$ & $<1.0$ & $<1.0$ & $<1.0$ & $<1.0$ & $<5.0$ & - & $<50$ & $<200$ & $<.1$ & 6.7 & 9 \\
\hline Mld-GD & $<1.0$ & $<1.0$ & $<1.0$ & $<1.0$ & $<1.0$ & $<5.0$ & - & $<50$ & $<200$ & 7.4 & 19 & 47 \\
\hline Snk-KH & $<1.0$ & $<1.0$ & $<1.0$ & $<1.0$ & $<1.0$ & $<5.0$ & $<5.0$ & $<50$ & $<200$ & 3.6 & 3.8 & 16 \\
\hline Snk-CJ & $<1.0$ & $<1.0$ & $<1.0$ & $<1.0$ & $<1.0$ & $<5.0$ & $<11$ & $<50$ & $<200$ & 8.7 & 8.3 & 19 \\
\hline Snk-BR & $<1.0$ & $<1.0$ & $<1.0$ & $<1.0$ & $<1.0$ & $<5.0$ & $<5.0$ & $<50$ & $<200$ & 5.4 & 21 & 30 \\
\hline Snk-MM & $<1.0$ & $<1.0$ & $<1.0$ & $<1.0$ & $<1.0$ & $<5.0$ & $<5.0$ & $<50$ & $<200$ & 3.5 & 9.5 & 7 \\
\hline
\end{tabular}


Appendix 3. Trace elements in fish-tissue samples from the Snake River Basin, 1992-97

[All sites are in Idaho unless otherwise noted; sites are shown in figure 3; OR, Oregon; all concentrations are in units of micrograms per gram (dry weight) unless otherwise noted; to convert dry-weight concentrations to wet-weight concentrations, multiply the dry-weight concentration by a factor of 1 minus the percentage moisture content expressed as a decimal; <, less than]

\begin{tabular}{|c|c|c|c|c|c|c|c|c|c|c|}
\hline \multirow{2}{*}{$\begin{array}{c}\text { Site } \\
\text { identification }\end{array}$} & \multirow[b]{2}{*}{ Site name } & \multirow{2}{*}{$\begin{array}{l}\text { Date sampled } \\
(\mathrm{mm} / \mathrm{dd} / \mathrm{yy})\end{array}$} & \multirow{2}{*}{$\begin{array}{l}\text { Fish species } \\
\text { sampled }\end{array}$} & \multirow{2}{*}{$\begin{array}{l}\text { Body part } \\
\text { analyzed }\end{array}$} & \multicolumn{6}{|c|}{ Trace element } \\
\hline & & & & & Aluminum & Antimony & Arsenic & Barium & Beryllium & Boron \\
\hline Hfk-RX & Henrys Fork near Rexburg & 08/06/96 & Utah sucker & Liver & 1.1 & $<0.2$ & 0.4 & $<0.1$ & $<0.2$ & 0.5 \\
\hline Snk-BF & Snake River near Blackfoot & 09/10/96 & Utah sucker & Liver & $<1.0$ & $<.2$ & 1.0 & $<.1$ & $<.2$ & .3 \\
\hline Prt-PC & Portneuf River at Pocatello & $09 / 09 / 96$ & Utah sucker & Liver & 3.5 & $<.3$ & .5 & .3 & $<.3$ & .5 \\
\hline Snk-MD & Snake River near Minidoka & $07 / 21 / 93$ & Utah sucker & Liver & $<1.0$ & $<.1$ & .4 & $<.1$ & $<.1$ & .2 \\
\hline Snk-KI & Snake River near Kimberly & $08 / 25 / 92$ & Utah sucker & Liver & $<1.0$ & .2 & .5 & $<.1$ & $<.2$ & 6 \\
\hline Rck-TF & Rock Creek at Twin Falls & 07/29/96 & Bridgelip sucker & Liver & 480 & $<.2$ & 1.8 & 7.4 & $<.2$ & 1.8 \\
\hline Snk-BU & Snake River near Buhl & $07 / 23 / 96$ & Largescale sucker & Liver & 17 & $<.2$ & .7 & .3 & $<.2$ & .6 \\
\hline Snk-KH & Snake River at King Hill & 07/29/97 & Largescale sucker & Liver & 15 & $<.2$ & .8 & .3 & $<.2$ & $<.4$ \\
\hline Snk-CJ & C.J. Strike Reservoir at Highway 51 Bridge & 08/04/97 & Largescale sucker & Liver & 17 & $<.2$ & .4 & .5 & $<.2$ & .4 \\
\hline Snk-CJ & C.J. Strike Reservoir at Highway 51 Bridge & 08/04/97 & Smallmouth bass & Fillet & $<.1$ & $<.2$ & 6 & .2 & $<.2$ & 1.0 \\
\hline Snk-CJ & C.J. Strike Reservoir at Highway 51 Bridge & 08/04/97 & Yellow perch & Fillet & $<.1$ & $<.3$ & $<.3$ & .4 & $<.3$ & .7 \\
\hline Snk-SF & Swan Falls Reservoir at Swan Falls Dam & 08/05/97 & Largescale sucker & Liver & 3.7 & $<.2$ & .8 & .1 & $<.2$ & .3 \\
\hline Boi-TS & Boise River at Twin Springs & 09/04/97 & Largescale sucker & Liver & 13 & $<.2$ & .8 & .1 & $<.2$ & $<.4$ \\
\hline Boi-PM & Boise River at Parma & $12 / 11 / 96$ & Largescale sucker & Liver & 4.4 & $<.1$ & .5 & .1 & $<.1$ & .4 \\
\hline Snk-NY & Snake River at Nyssa, OR & 08/06/97 & Largescale sucker & Liver & 4.2 & $<.2$ & 6 & .2 & $<.2$ & .3 \\
\hline Snk-NY & Snake River at Nyssa, OR & 08/06/97 & Channel catfish & Fillet & $<1.0$ & $<.2$ & $<.2$ & $<.1$ & $<.2$ & .8 \\
\hline Snk-BR & Brownlee Reservoir at Burnt River, OR & 08/11/97 & Largescale sucker & Liver & 13 & $<.2$ & .3 & .2 & $<.2$ & .3 \\
\hline Snk-BR & Brownlee Reservoir at Burnt River, OR & 08/11/97 & Common carp & Liver & 24 & $<.1$ & .5 & .3 & $<.1$ & .4 \\
\hline Snk-BR & Brownlee Reservoir at Burnt River, OR & 08/11/97 & Smallmouth bass & Fillet & 2.8 & $<.2$ & .7 & .4 & $<.2$ & .7 \\
\hline Snk-BR & Brownlee Reservoir at Burnt River, OR & $08 / 11 / 97$ & White crappie & Fillet & $<.1$ & $<.3$ & .5 & .4 & $<.3$ & 6 \\
\hline Snk-BR & Brownlee Reservoir at Burnt River, OR & 08/11/97 & Channel catfish & Fillet & 1.1 & $<.2$ & $<.2$ & $<.1$ & $<.2$ & 1.0 \\
\hline Snk-PL & Snake River at Pittsburg Landing & 08/13/97 & Largescale sucker & Liver & 14 & $<.2$ & .6 & .2 & $<.2$ & .6 \\
\hline Snk-PL & Snake River at Pittsburg Landing & 08/13/97 & Largescale sucker & Liver & 51 & $<.2$ & .7 & 1.0 & $<.2$ & .5 \\
\hline Sal-WB & Salmon River near White Bird & 08/14/97 & Largescale sucker & Liver & 110 & $<.3$ & .9 & 1.2 & $<.3$ & $<.5$ \\
\hline
\end{tabular}




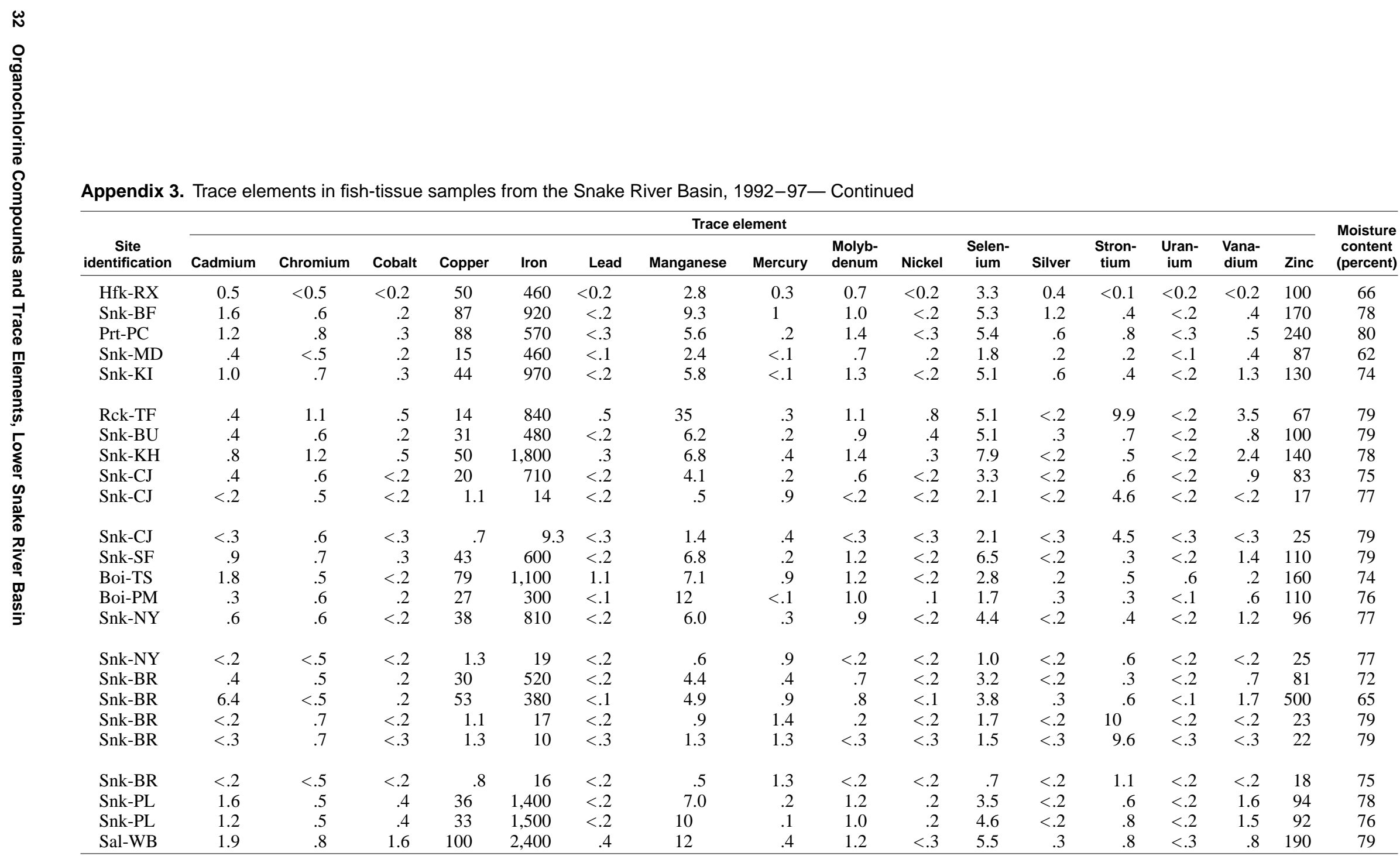


Appendix 4. Trace elements in bed-sediment samples from the Snake River Basin, 1992-97

[All sites are in Idaho unless otherwise noted; sites are shown in figure 3; WY, Wyoming; OR, Oregon; all concentrations are in units of micrograms per gram (dry weight) unless otherwise noted; <, less than; - , no data available]

\begin{tabular}{|c|c|c|c|c|c|c|c|c|c|c|c|c|c|}
\hline \multirow[b]{2}{*}{$\begin{array}{c}\text { Site } \\
\text { identification }\end{array}$} & \multirow[b]{2}{*}{ Site name } & \multirow[b]{2}{*}{$\begin{array}{c}\text { Date } \\
\text { sampled } \\
(\mathrm{mm} / \mathrm{dd} / \mathrm{yy})\end{array}$} & \multicolumn{11}{|c|}{ Trace element } \\
\hline & & & $\begin{array}{c}\text { Alumi- } \\
\text { num } \\
\text { (percent) }\end{array}$ & $\begin{array}{l}\text { Anti- } \\
\text { mony }\end{array}$ & Arsenic & Barium & $\begin{array}{l}\text { Beryl- } \\
\text { lium }\end{array}$ & Bismuth & Cadmium & Cerium & $\begin{array}{l}\text { Chro- } \\
\text { mium }\end{array}$ & Cobalt & Copper \\
\hline Snk-FR & Snake River at Flagg Ranch, WY & 09/06/95 & 5.6 & 1.0 & 17 & 660 & 4 & $<10$ & 0.5 & 90 & 39 & 7 & 11 \\
\hline Slt-FC & Salt River near Fish Creek, WY & $08 / 12 / 93$ & 6.0 & .3 & 6.0 & 22 & 1 & $<10$ & .9 & 64 & 66 & 10 & 22 \\
\hline Slt-ET & Salt River near Etna, WY & $08 / 16 / 94$ & 4.8 & .3 & 6.6 & 390 & 1 & $<10$ & 6 & 40 & 49 & 9 & 16 \\
\hline Btc-LA & Bitch Creek near Lamont & $09 / 14 / 93$ & 6.1 & $<.2$ & 5.9 & 21 & 2 & $<10$ & .3 & 120 & 90 & 12 & 21 \\
\hline Hfk-RX & Henrys Fork near Rexburg & 08/16/93 & 5.5 & .3 & 6.3 & 16 & 5 & $<10$ & .4 & 110 & 69 & 9 & 16 \\
\hline Bkt-HE & Blackfoot River near Henry & 09/22/92 & 4.6 & $<.2$ & 3.9 & 470 & 1 & $<10$ & 1.5 & 53 & 62 & 9 & 12 \\
\hline Snk-BF & Snake River near Blackfoot & $09 / 07 / 93$ & 4.6 & .3 & 6.6 & 13 & 2 & $<10$ & .3 & 67 & 52 & 8 & 13 \\
\hline Prt-PC & Portnuef River at Pocatello & $09 / 17 / 92$ & 4.8 & .3 & 4.6 & - & 1 & $<10$ & .9 & 59 & 66 & 8 & 23 \\
\hline Snk-MD & Snake River near Minidoka & $07 / 22 / 93$ & 4.3 & $<.2$ & 4.2 & 15 & 2 & $<10$ & .3 & 48 & 43 & 8 & 15 \\
\hline Snk-KI & Snake River near Kimberly & 08/27/92 & 3.9 & $<.2$ & 4.9 & 560 & 1 & $<10$ & .3 & 59 & 47 & 7 & 15 \\
\hline Rck-RK & Rock Creek near Rock Creek & 07/06/93 & 6.0 & .5 & 4.9 & 15 & 3 & $<10$ & 1.0 & 130 & 48 & 6 & 15 \\
\hline Rck-TF & Rock Creek at Twin Falls & 07/21/97 & 5.1 & .7 & 4.7 & 580 & 1 & $<10$ & .3 & 85 & 63 & 7 & 12 \\
\hline Snk-BU & Snake River near Buhl & 07/20/93 & 5.2 & .3 & 4.5 & 21 & 1 & $<10$ & .3 & 80 & 66 & 9 & 21 \\
\hline Bgl-CL & Big Lost River near Chilly & 08/29/94 & 6.3 & 2.0 & 15 & 1,100 & 2 & $<10$ & 1.8 & 69 & 95 & 15 & 34 \\
\hline Bgw-KE & Big Wood River near Ketchum & $07 / 26 / 93$ & 7.3 & 1.0 & 18 & 25 & 3 & $<10$ & .5 & 150 & 140 & 15 & 25 \\
\hline Mld-GD & Malad River near Gooding & $08 / 26 / 93$ & 5.9 & .5 & 4.7 & 22 & 2 & $<10$ & .5 & 75 & 72 & 9 & 22 \\
\hline Snk-KH & Snake River at King Hill & 07/28/97 & 5.4 & .5 & 4.4 & 550 & 1 & $<10$ & .4 & 86 & 110 & 11 & 16 \\
\hline Snk-CJ & C.J. Strike Reservoir at Highway 51 Bridge & 08/04/97 & 5.2 & .5 & 4.4 & 520 & 1 & $<10$ & .4 & 69 & 58 & 8 & 18 \\
\hline Snk-BR & Brownlee Reservoir at Burnt River, OR & 08/12/97 & 7.2 & .7 & 8.8 & 670 & 2 & $<10$ & .4 & 73 & 74 & 17 & 34 \\
\hline Snk-MM & Brownlee Reservoir at Mountain Man & 08/12/97 & 7.6 & 3.1 & 14 & 650 & 2 & $<10$ & 2.3 & 75 & 110 & 24 & 62 \\
\hline
\end{tabular}


Appendix 4. Trace elements in bed-sediment samples from the Snake River Basin, 1992-97-Continued

\begin{tabular}{|c|c|c|c|c|c|c|c|c|c|c|c|c|c|c|c|}
\hline \multirow[b]{2}{*}{$\begin{array}{c}\text { Site } \\
\text { identification }\end{array}$} & \multicolumn{15}{|c|}{ Trace element } \\
\hline & Europium & Gallium & Gold & Holmium & $\begin{array}{c}\text { Iron } \\
\text { (percent) }\end{array}$ & Lanthanum & Lead & Lithium & Manganese & Mercury & Molybdenum & Neodymium & Nickel & Niobium & Scandium \\
\hline Snk-FR & $<2$ & 13 & $<8$ & $<4$ & 2.1 & 46 & 22 & 30 & 460 & 0.04 & $<2$ & 37 & 15 & 14 & 6 \\
\hline Slt-FC & $<2$ & 14 & $<8$ & $<4$ & 2.5 & 37 & 13 & 40 & 460 & $<.02$ & $<2$ & 31 & 22 & 13 & 9 \\
\hline Slt-ET & $<2$ & 11 & $<8$ & $<4$ & 1.9 & 24 & 11 & 30 & 530 & $<.02$ & $<2$ & 18 & 17 & 11 & 7 \\
\hline Btc-LA & $<2$ & 18 & $<8$ & $<4$ & 2.9 & 74 & 17 & 40 & 520 & $<.02$ & $<2$ & 61 & 28 & 22 & 10 \\
\hline Hfk-RX & $<2$ & 15 & $<8$ & $<4$ & 2.6 & 62 & 16 & 30 & 550 & $<.02$ & $<2$ & 51 & 19 & 20 & 9 \\
\hline Bkt-HE & $<2$ & 11 & $<8$ & $<4$ & 2.1 & 31 & 15 & 30 & 830 & .03 & $<2$ & 26 & 19 & 7 & 7 \\
\hline Snk-BF & $<2$ & 11 & $<8$ & $<4$ & 2.0 & 39 & 12 & 30 & 580 & $<.02$ & $<2$ & 32 & 17 & 13 & 7 \\
\hline Prt-PC & 37 & 11 & $<8$ & $<4$ & 2.0 & 37 & 39 & 30 & 390 & .06 & $<2$ & 30 & 19 & 10 & 7 \\
\hline Snk-MD & $<2$ & 12 & $<8$ & $<4$ & 2.0 & 28 & 13 & 30 & 620 & $<.02$ & $<2$ & 23 & 17 & 11 & 6 \\
\hline Snk-KI & $<2$ & 10 & $<8$ & $<4$ & 2.0 & 34 & 13 & 20 & 430 & .04 & $<2$ & 28 & 24 & 9 & 6 \\
\hline Rck-RK & $<2$ & 16 & $<8$ & $<4$ & 2.4 & 68 & 18 & 30 & 450 & .06 & $<2$ & 54 & 12 & 24 & 8 \\
\hline Rck-TF & $<2$ & 14 & $<8$ & $<4$ & 2.1 & 46 & 13 & 23 & 470 & .03 & $<2$ & 38 & 14 & 16 & 7 \\
\hline Snk-BU & $<2$ & 12 & $<8$ & $<4$ & 2.4 & 45 & 13 & 30 & 430 & .02 & $<2$ & 38 & 17 & 15 & 8 \\
\hline Bgl-CL & $<2$ & 16 & $<8$ & $<4$ & 3.2 & 46 & 27 & 40 & 550 & .07 & $<2$ & 35 & 53 & 19 & 11 \\
\hline Bgw-KE & $<2$ & 22 & $<8$ & $<4$ & 3.8 & 88 & 42 & 50 & 690 & .02 & $<2$ & 61 & 39 & 26 & 13 \\
\hline Mld-GD & $<2$ & 15 & $<8$ & $<4$ & 2.9 & 43 & 17 & 40 & 370 & $<.02$ & $<2$ & 36 & 25 & 15 & 10 \\
\hline Snk-KH & $<2$ & 15 & $<8$ & $<4$ & 2.8 & 47 & 14 & 26 & 480 & .06 & $<2$ & 39 & 21 & 15 & 9 \\
\hline Snk-CJ & $<2$ & 14 & $<8$ & $<4$ & 2.4 & 38 & 13 & 28 & 490 & .04 & $<2$ & 33 & 18 & 12 & 8 \\
\hline Snk-BR & $<2$ & 19 & $<8$ & $<4$ & 4.4 & 39 & 24 & 32 & 1,000 & .06 & $<2$ & 38 & 25 & 21 & 14 \\
\hline Snk-MM & $<2$ & 19 & $<8$ & $<4$ & 5.3 & 39 & 23 & 39 & 970 & .13 & $<2$ & 38 & 48 & 19 & 18 \\
\hline
\end{tabular}


Appendix 4. Trace elements in bed-sediment samples from the Snake River Basin, 1992-97 — Continued

\begin{tabular}{|c|c|c|c|c|c|c|c|c|c|c|c|c|c|c|}
\hline \multirow[b]{2}{*}{$\begin{array}{c}\text { Site } \\
\text { identification }\end{array}$} & \multicolumn{12}{|c|}{ Trace element } & \multirow{2}{*}{$\begin{array}{c}\text { Inorganic } \\
\text { carbon } \\
\text { (percent) }\end{array}$} & \multirow{2}{*}{$\begin{array}{c}\text { Organic } \\
\text { carbon } \\
\text { (percent) }\end{array}$} \\
\hline & Selenium & Silver & Strontium & Tantalum & Thorium & Tin & $\begin{array}{l}\text { Titanium } \\
\text { (percent) }\end{array}$ & Uranium & Vanadium & Ytterbium & Yttrium & Zinc & & \\
\hline Snk-FR & 0.5 & 0.2 & 140 & $<40$ & 12 & $<5$ & 0.26 & 5.2 & 60 & 3 & 30 & 100 & 0.20 & 1.81 \\
\hline Slt-FC & .8 & .2 & 130 & $<40$ & 10 & $<5$ & .30 & 4.2 & 81 & 2 & 24 & 83 & .61 & 1.84 \\
\hline Slt-ET & .7 & .2 & 200 & $<40$ & 10 & $<5$ & .19 & 3.3 & 64 & 2 & 17 & 79 & 2.80 & 2.33 \\
\hline Btc-LA & .4 & .2 & 120 & $<40$ & 19 & $<5$ & .31 & 5.5 & 68 & 5 & 55 & 82 & 1.14 & 2.82 \\
\hline Hfk-RX & .4 & .2 & 150 & $<40$ & 14 & $<5$ & .33 & 5.2 & 63 & 4 & 44 & 92 & .33 & 1.89 \\
\hline Bkt-HE & 1.3 & .1 & 180 & $<40$ & 9 & $<5$ & .20 & 3.6 & 57 & 2 & 22 & 110 & 1.42 & 2.74 \\
\hline Snk-BF & .7 & .2 & 220 & $<40$ & 9 & $<5$ & .24 & 3.4 & 57 & 2 & 22 & 71 & 1.83 & 2.42 \\
\hline Prt-PC & .6 & .2 & 250 & $<40$ & 10 & $<10$ & .24 & 4.1 & 59 & 2 & 22 & 110 & 1.57 & 2.22 \\
\hline Snk-MD & 1.4 & .1 & 280 & $<40$ & 7 & $<5$ & .19 & 2.3 & 52 & 2 & 17 & 78 & 2.71 & 4.58 \\
\hline Snk-KI & 1.4 & $<.1$ & 320 & $<40$ & 9 & $<5$ & .22 & 5.1 & 52 & 2 & 19 & 62 & 3.23 & 2.80 \\
\hline Rck-RK & .8 & .3 & 190 & $<40$ & 16 & $<5$ & .37 & 5.7 & 49 & 5 & 52 & 98 & $<.01$ & 2.89 \\
\hline Rck-TF & .3 & .2 & 220 & $<40$ & 11 & $<5$ & .35 & 4.3 & 63 & 3 & 25 & 66 & 1.08 & .78 \\
\hline Snk-BU & .5 & .2 & 240 & $<40$ & 12 & $<5$ & .35 & 4.0 & 68 & 2 & 23 & 78 & 1.27 & 1.20 \\
\hline Bgl-CL & 2.5 & .5 & 210 & $<40$ & 15 & $<5$ & .33 & 9.1 & 130 & 2 & 23 & 240 & .07 & 4.52 \\
\hline Bgw-KE & 1.1 & .5 & 280 & $<40$ & 61 & $<5$ & .38 & 25 & 97 & 3 & 35 & 140 & $<.01$ & 3.69 \\
\hline Mld-GD & .7 & .2 & 240 & $<40$ & 10 & $<5$ & .36 & 3.6 & 76 & 2 & 22 & 100 & 1.11 & 2.47 \\
\hline Snk-KH & .5 & .2 & 230 & $<40$ & 15 & $<5$ & .42 & 4.0 & 86 & 2 & 25 & 86 & 1.11 & .94 \\
\hline Snk-CJ & .6 & .2 & 250 & $<40$ & 10 & $<5$ & .32 & 3.1 & 70 & 2 & 23 & 72 & 1.67 & 1.31 \\
\hline Snk-BR & .5 & .2 & 300 & $<40$ & 10 & $<5$ & .61 & 2.9 & 120 & 3 & 29 & 110 & .73 & 1.79 \\
\hline Snk-MM & 1.4 & .4 & 230 & $<40$ & 12 & $<5$ & .59 & 3.5 & 180 & 3 & 32 & 250 & .44 & 1.92 \\
\hline
\end{tabular}

